HENRY CURTIS

\title{
IS THERE ANY OTHER WAY? PORT STATE JURISDICTION AS AN ALTERNATIVE TO THE MANDATORY REFLAGGING OF DEEP WATER FISHING VESSELS IN NEW ZEALAND'S EEZ
}

RESEARCH PAPER

LAWS 528: LAW OF THE SEA

FACULTY OF LAW

TE Whare wánanga o te Úpoko o te ika a māui

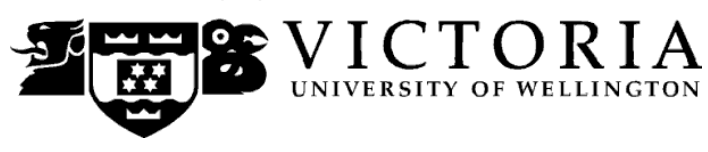

2014 


\section{Table of Content}

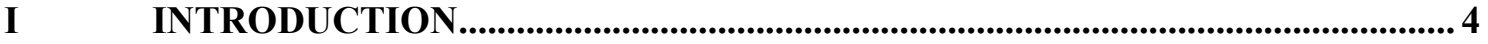

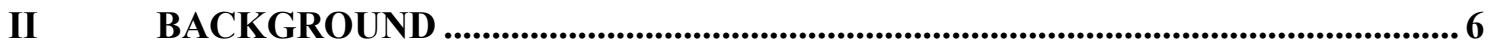

III INTERNATIONAL LAW RELEVANT TO FISHING VESSELS IN THE

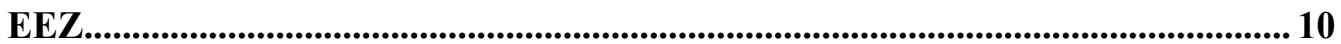

A UNCLOS and Coastal State jurisdiction over foreign vessels ................................. 11

B Extra-Territorial Jurisdiction............................................................................................. 14

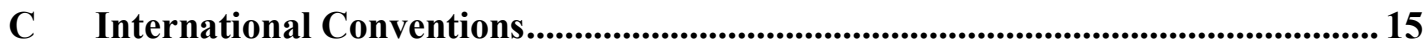

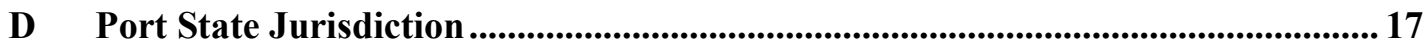

E Summary of section.............................................................................................................. 21

IV THE LEGAL REGIMES FOR FCVS PRE AND POST-2014 .............................. 21

A Foreign Charter Vessels under the Fisheries Act 1996............................................ 22

B The Fisheries Amendment Act - Immediate Changes................................................ 24

C The Fisheries Amendment Act - Reflagging Fishing Vessels ................................... 25

D The effect of the changes on the fishing industry in New Zealand ........................26

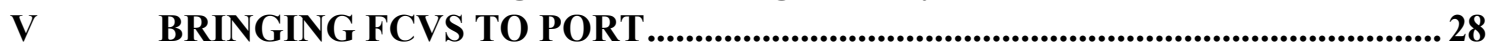

VI CONSTRUCTION, DESIGN, AND EQUIPMENT STANDARDS ....................... 29

A The regime for FCV safety, pre-2014 ......................................................................... 29

B Through the use of Port State Jurisdiction ..........................................................30

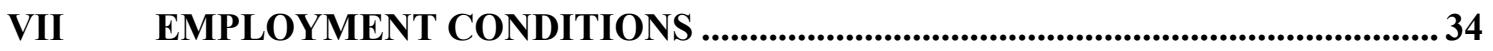

A The Fisheries Act and the Code of Practice.................................................................... 34

B Through the use of Port State Jurisdiction ...................................................................... 37

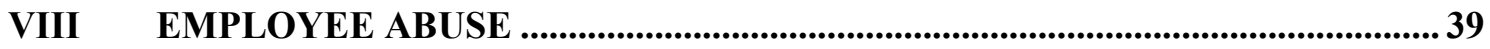

A The Fisheries Act, pre-2014................................................................................................... 39

B Through the use of Port State Jurisdiction .................................................................... 41

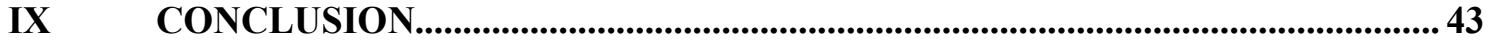

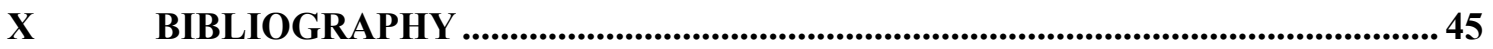

A Journal Articles ................................................................................................................. 45

B Books and Chapters in Edited Books ............................................................................. 46

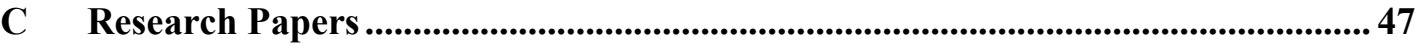

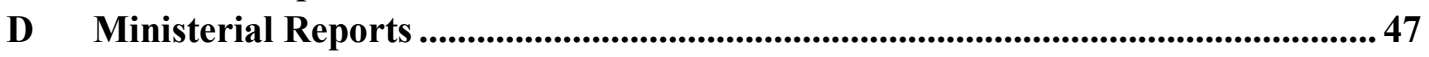

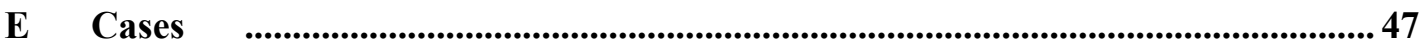

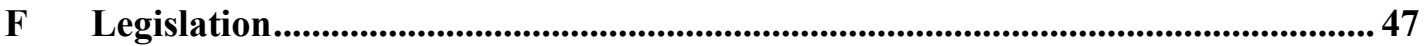

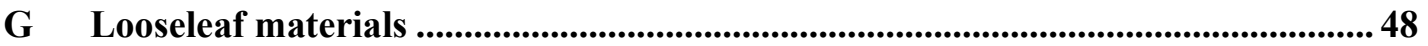

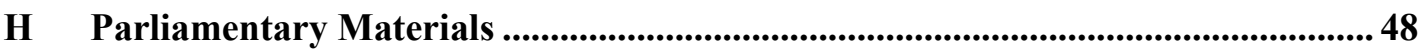

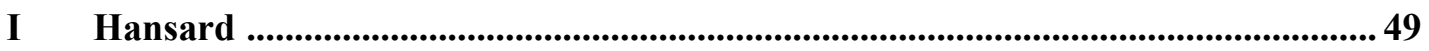

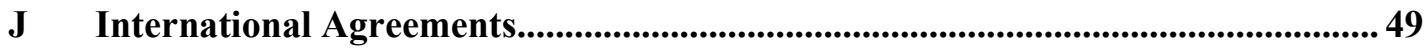

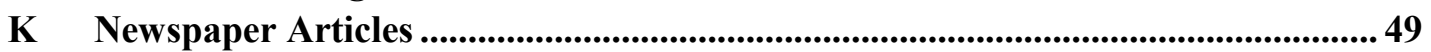

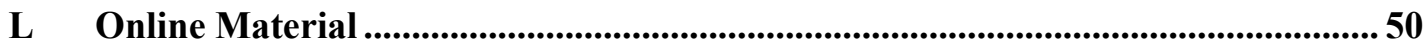

M Speeches ....................................................................................................................................... 50 


\begin{abstract}
This paper examines the recent changes in New Zealand to require fishing vessels operating in New Zealand waters to be exclusively New Zealand flagged ships, rather than foreign charter vessels as has been practiced to date. Drawing on scholarship regarding the increase in States using measures of port State jurisdiction to regulate foreign vessels throughout zones both in and outside their jurisdiction, the paper asks the question; can a State regulate foreign fishing vessels in its EEZ in a manner consistent with its ability to regulate its own vessels? After establishing the scope of jurisdiction a State holds over vessels in its respective maritime zones (including its ports), this paper goes on to examine the cases of abuse, substandard vessel conditions, and underpayment of workers highlighted on foreign fishing vessels in New Zealand and their possible regulation. The paper ultimately concludes that the application of port State jurisdiction is limited in its ability to regulate foreign EEZ fishing vessels. While some aspects of foreign vessel operation in the EEZ can be regulated to the same extent as domestic vessels, the nature of some offences on board foreign fishing vessels leaves them beyond the jurisdiction of the coastal State.
\end{abstract}

\title{
Word length
}

The text of this paper (excluding abstract, table of contents, footnotes and bibliography) comprises approximately 15005 words.

\section{Subjects and Topics}

Port State jurisdiction - foreign charter vessels - exclusive economic zone - employment law - Fisheries Act 1996 


\section{Introduction}

When introducing the Fisheries (Foreign Charter Vessels and Other Matters) Amendment Bill ('Fisheries Amendment Act') to the house for its second reading the Honourable Jo Goodhew, on behalf of the Minister of Primary Industries, described the bill as 'a crucial piece of legislation...necessary to ensure that health and safety requirements on all fishing vessels in New Zealand waters are of the highest standard.' ${ }^{1}$ The bill was the end result of domestic and international pressure on the New Zealand Government, and a subsequent Ministerial Enquiry into the use of Foreign Charter Vessels (FCV) to harvest quota owned by New Zealand parties within New Zealand's Exclusive Economic Zone. While FCVs had proved an economical way for New Zealand fisheries quota owners to exploit their allocated catch, they were also the subject of repeated reports of severely deficient working and accommodation environments, as well as the exploitation and abuse of foreign fishermen working on board the vessels.

The Fisheries Amendment Act, given royal assent on in August of 2014, amends the Fisheries Act 1996, immediately granting the Chief Executive of the Ministry of Primary Industries (MPI) the power to suspend the registration of any vessel which does not comply with the relevant conditions. ${ }^{2}$ However, more significantly, from May 2016 fishing vessels will only be permitted to operate to take catch from a New Zealand fishery if that vessel is a New Zealand registered ship. ${ }^{3}$ The amendments bring to an end the tradition of using FCVs to exploit New Zealand owned quota, a practice which at the implementation of New Zealand's Quota Management System (QMS) was intended as temporary, ${ }^{4}$ but which grew to represent close to half the fishing vessels operating in the EEZ. ${ }^{5}$ In addressing the welfare of workers onboard fishing vessels in the EEZ, the amendments remove any ambiguity resulting from the interplay between coastal and flag State jurisdiction on FCVs, ambiguities which facilitated vessel standards below those of New Zealand, and impeded the monitoring and enforcement of health and safety infringements and instances of outright abuse.

\footnotetext{
1 (15 April 2014) 698 NZPD 17281

${ }^{2}$ Fisheries (Foreign Charter Vessels and Other Matters) Amendment Act 2014, s 5.

${ }^{3}$ Fisheries Amendment Act 2014, s 8.

${ }^{4}$ Paul Swain, Sarah McGrath and Neil Walter Report of the Ministerial Inquiry into the use and operation of Foreign Charter Vessels (Ministry of Agriculture and Forestry, February 2012) at 13.

${ }^{5}$ Swain et al, above $\mathrm{n} 4$, at 22.
} 
While some scholars have noted that the move to exclusive use of domestically registered fishing vessels within the EEZ brings New Zealand practice in line with that of other developed nations, ${ }^{6}$ the relative immaturity of New Zealand's fishing industry to nations of comparable EEZs should also be noted. ${ }^{7}$ In her research paper on the Ministerial Enquiry into the use of FCVs, Hannah Brown States that 'reflagging is the only way to comprehensively implement New Zealand law in relation to the labour conditions on deepsea vessels. ${ }^{8}$ Recognizing the potential benefits gained through using FCVs to fully exploit New Zealand's Total Allowable Catch (TAC), this paper assesses whether the clarity of jurisdiction over worker's rights and vessel standards gained through the mandatory registration of fishing vessels could be gained in equal measure through the use of port State jurisdiction to regulate FCVs in New Zealand.

This paper will begin by giving a brief overview of the use of FCVs in New Zealand fisheries, from the origin of the practice to the ongoing exposure of abuse and exploitation. Following this, the international law which provides the framework for coastal State jurisdiction over foreign vessels will be discussed. The New Zealand regime for regulating the use of FCVs will be outlined in a general sense, both in its current iteration, as well as before the passing of the Fisheries Amendment Act. The full significance of the changes to require the use of New Zealand ships in New Zealand's EEZ will be explored, including the practical implications for operators currently utilizing FCVs to fulfil quota holdings.

Having established the various legal regimes (international and domestic) within which FCVs are operated, the final sections of this paper will include an analysis of the fundamental flaws in the system relating to jurisdiction over the following distinct areas: vessel construction, design, and equipment standards; employment agreements, including labour conditions, wages, and workplace health and safety; and finally criminal abuse. For each area, specific details of the pre-2014 regime for FCV regulation will be explored, including the practical difficulties of pursuing complaints where such an avenue existed for workers. How the changes arising from the Fisheries Amendment Act effect these specific areas will be explored. Finally, drawing on recent scholarship and State practice regarding the increasing use of port State jurisdiction to enforce

${ }^{6}$ Peter Dawson and Renee Hunt 'The Legal Regime Governing the Operation of Foreign Charter Fishing Vessels in New Zealand' (2011) 25 Austl. \& N.Z. L.J. 195, at 199

${ }^{7}$ Swain et al, above $\mathrm{n} 4$, at 24

${ }^{8}$ Hannah Brown "A fine kettle of fish: Employment conditions on foreign charter vessels in New Zealand's Exclusive Economic Zone” (LLB (Hons) dissertation, Victoria University of Wellington, 2012), at 27 
requirements on foreign flagged vessels, the possibility of achieving the intent of the Fisheries Amendment Act through port State jurisdiction will be explored for each area. As the focus of this essay is on the welfare and employment conditions for workers on FCVs fishing within the EEZ, the legal regime for environmental protection and conservation, including the management of fish stocks and the regulation of vessel source pollution, are generally outside the scope of this essay, as is the regulation of fishing within the $12 \mathrm{~nm}$ territorial sea.

\section{Background}

Initially intended as a temporary measure, following the establishment of the EEZ through the Territorial Sea, Contiguous Zone, and Exclusive Economic Zone Act 1977, the presence of foreign vessels fishing in those waters continued through the basis of country to country agreements. When the QMS was introduced in 1983, the New Zealand government continued to allow quota holders the use of FCVs to fully exploit their holdings, in order to facilitate the fishing industry as it grew to a suitable capacity. ${ }^{9}$ By the mid-1990s, what had begun as a temporary measure now saw a domestic EEZ fishing fleet comprised of approximately 75\% FCVs. As the number of domestic and foreign vessels fishing the EEZ has reduced in recent years, this figure, while still significant, has moved closer to $50 \% .{ }^{10}$ Significantly, the majority of these vessels were, and remain, chartered under a time charter arrangement, being fully equipped, manned and operated by a foreign owner, but being directed as to the place and nature of its catch by a New Zealand Charter Party (NZCP). In 2011, of the 27 FCVs operating, only one was operating under a demise (or bareboat) charter arrangement, with all control and management of the vessels going to the NZCP, and only the ownership remaining with the overseas charter party. ${ }^{11}$

The sinking of the Korean flagged fishing vessel Oyang 70 is often quoted as the catalyst for the recent changes to the legal regime for fishing vessels operating within New Zealand's EEZ. At the time of the incident, the vessel had been operating as a trawler in the EEZ for eight years under a time charter arrangement. ${ }^{12}$ Despite being 38 years old, the vessel had recently passed a safety inspection administered by Maritime New Zealand

\footnotetext{
${ }^{9}$ Swain et al, above $\mathrm{n} 4$, at 13-14

${ }^{10}$ Swain et al, above $\mathrm{n} 4$, at 22

${ }^{11}$ Swain et al, above $\mathrm{n} 4$, at 22

${ }^{12}$ Christina Stringer, Glenn Simmons and Daren Coulston "Not in New Zealand's waters, surely? Linking labour issues to GPNs" (2013) 14 Journal of Economic Geography 739, at 739
} 
$(\mathrm{MNZ}){ }^{13}$ the government regulatory agency for merchant ship operations in New Zealand waters. On 18 August 2010, the vessel sank off the coast of New Zealand, resulting in the loss of six lives and the rescue of 45 remaining crew members by the New Zealand flagged vessel the Amaltal Atlantis. ${ }^{14}$

Following their rescue, the surviving crew members of the Oyang 70 described to their rescuers details of the circumstances of their employment on-board the vessel, which has since been widely described as modern day slavery. A research paper conducted by the University of Auckland quickly established that these conditions were prevalent throughout the FCV fleet operating in the EEZ, particularly onboard those FCVs flagged to Korea. ${ }^{15}$ A large number of interviewees described the standard of the vessels as being substantially below that expected of a New Zealand ship, with fishermen provided accommodation which was poorly ventilated, wet, with no heating, and with infestations of pests. ${ }^{16}$ Food was inadequate, often consisting of only fish, rice, and rusty untreated water. Crews were forced to work long hours, meaning injury through fatigue was a constant and serious risk for those operating fish processing machinery. ${ }^{17}$ Those who were injured often had to wait days for treatment, and were then quickly put back to work, or were expelled by the ship and sent home with nothing. ${ }^{18}$

Despite New Zealand requirements for employment agreements, vessel operators and overseas manning agents in Korea and Indonesia routinely exploited workers. Minimum wage requirements were flouted by operators, who paid insufficient wages and for fewer hours than had actually been worked. Crew were sometimes paid as little as \$US230 a month, and this was following an initial three month pay deduction as a fee for the overseas manning agent. Multiple and contradictory contracts were signed by workers, the one representing compliance with New Zealand regulations only being presented when required by New Zealand authorities. Wages actually paid were subject to deductions by the operator, and the manning agent. ${ }^{19}$ Instances of abuse against crew members were also reported as common. These reports of physical abuse included beatings and forced punishments, including prolonged periods of standing above deck in

\footnotetext{
${ }^{13}$ Dawson and Hunt, above $\mathrm{n} 6$, at 195

${ }^{14}$ Stringer et al, above $\mathrm{n} 12$, at 739

${ }^{15}$ See Stringer et al, above $\mathrm{n} 12$

${ }^{16}$ Stringer et al, above $\mathrm{n} 12$, at 746

${ }^{17}$ Stringer et al, above $\mathrm{n} 12$, at 747

${ }^{18}$ Benjamin E. Skinner "Fishing as Slaves on the High Seas" Bloomberg Businessweek (United States of America, 20 February 2012), at 72

${ }^{19}$ Stringer et al, above n 12 , at 749
} 
extreme weather conditions. Sexual abuse including rape was also reported. Officers of the vessels, aware that they were under the jurisdiction of the flag State of the vessel, apparently undertook this abuse without any concern of enforcement by New Zealand authorities. $^{20}$

The incentives crew had to leave these employment conditions were diminished by threats of fines from manning agents against the workers and their families which would be imposed should the worker flee the vessel; these fines at times totaled more than the workers total financial holdings. ${ }^{21}$ This reluctance to leave was enhanced by the inability of workers to raise an income if they deserted the vessel, as the working visas issued to workers by Immigration New Zealand entitled the holder to work in the EEZ alone. Requirements for vessel operators to maintain strict policies for the workers' shore leave added further disincentive. ${ }^{22}$ Nevertheless, between 2005 and 2011, over 100 crew members of FCVs (not including those of the Oyang 70) fled or deserted their vessels, citing reasons of sexual, verbal and physical abuse, unpaid wages, long work hours or unacceptable working conditions. ${ }^{23}$

Significant and scathing publicity followed these reports, both at the domestic and international levels. Most significantly, the Bloomberg Business Week magazine undertook a six month investigation into FCV employee abuse in New Zealand, highlighting where American retailers were sourcing fisheries imports from New Zealand which the magazine termed as 'slave caught' and 'tainted'. ${ }^{24}$ Concurrently, in August 2011, the Minister of Labour and the Minister of Fisheries and Aquaculture initiated a Ministerial Inquiry into the mistreatment of workers onboard FCVs within New Zealand waters. The significance of the attention the reports of abuse had bought to the New Zealand fishing industry were captured in the terms of reference for the report, which included assurance from the panel that FCVs did not undermine New Zealand's international reputation and trade access. ${ }^{25}$

The report on the Enquiry, submitted in February 2014, offered a range of recommended changes to the regulatory regime for FCVs in order to provide greater compliance with

\footnotetext{
${ }^{20}$ Stringer et al, above $\mathrm{n} 12$, at 748

${ }^{21}$ Skinner, above $\mathrm{n} 18$, at 72

${ }^{22}$ Jennifer Devlin "Modern Day Slavery: Employment Conditions for Foreign Fishing Crews in New Zealand Waters" (2009) 23 Austl. \& N.Z. Mar. L.J. 82, at 91

${ }^{23}$ Stringer et al, above n 12 , at 745

${ }^{24}$ Skinner, above $\mathrm{n} 18$, at 76

${ }^{25}$ Swain et al, above $\mathrm{n} 4$, at 93
} 
fisheries rules. The report highlighted deficiencies in the existing regulatory regime which required remedy. Policy recommendations included the need for 'closer coordination among the key agencies...[as] a major weakness until now has been that the agencies have been operating in isolation, with little in the way of information sharing or coordinated decision making on FCV issues. ${ }^{26}$ Recommendations were largely focused on policy improvements, including increasing the rate of observers on FCV to $100 \%$ from $30 \%$, targeted monitoring of at risk vessels, higher standards of vessel safety inspections, and increased labour inspections and awareness of employment rights for workers on $\mathrm{FCVs}^{27}$

Some legislative amendments were recommended by the panel, although these fell short of recommending outright that vessel require reflagging to New Zealand if they wish to operate in the EEZ. Instead, amendments to the Fisheries Act were suggested which allowed for greater punishment of offending vessels through deregistration, effectively barring them from continued fisheries operation. Additionally, it was recommended that the Maritime Rules, the regulatory rule set of Maritime New Zealand, drawn from the Maritime Transport Act 1994, being amended to explicitly apply to FCVs. The extension of the Crimes Act 1961 (the Crimes Act) and the Health and Safety in Employment Act 1992 (the Health and Safety Act) to cover FCVs was recommended. The extension of New Zealand employment laws to FCVs was suggested through the banning of demise chartering, at which point the New Zealand Charter Party would the clear employer of the crew, having received only the vessel itself through the time charter arrangement. No legal solution for the extension of the Crimes Act was provided in the report. Additionally, the ratification of the two conventions of the International Maritime Organization, the 1993 Protocol to the Torremolinos International Convention for the Safety of Fishing Vessels (Torremolinos Protocol), and the International Conventions for the Standards of Training, Certification, and Watchkeeping for Fishing vessels (STCWF) be ratified into New Zealand law. ${ }^{28}$

While it was recognized that the requirement for the reflagging of would alleviate any ambiguity regarding New Zealand jurisdiction over EEZ fishing vessels, such a measure was seen by the panel as carrying unnecessary levels of economic risk to the New Zealand fishing industry, while also recognizing that the offending vessels were generally those of Korean origin, and that a large number of FCVs in New Zealand waters

\footnotetext{
${ }^{26}$ Swain et al, above $\mathrm{n} 4$, at 81

${ }^{27}$ Swain et al, above $n$, at $82-88$

${ }^{28}$ Swain et al, above $n$, at $88-92$
} 
complied appropriately with New Zealand requirements. The panel therefore limited this recommendation to amending the Fisheries Act to include 'an empowering provision for the reflagging to New Zealand of some or all FCVs operating in the EEZ, should this be deemed necessary in the national interest' (emphasis added). ${ }^{29}$ As it was, in May 2012 the Government of New Zealand announced its intension to reflag all EEZ fishing vessels by $2016,{ }^{30}$ while also adopting the policy related recommendations identified above. ${ }^{31}$

Aside from the reputational damage caused by the cases of abuse onboard FCVs, it is unsurprising that the clarity provided by mandatory registration of fishing vessels to New Zealand appealed so strongly to the New Zealand Government. Various measures have been taken by the New Zealand government since the introduction of the Fisheries Act, in an effort to address the issues highlighted above, all of which have proved largely ineffective. The most significant of these was the non-binding Code of Practice on Foreign Fishing Crews, which sought to ensure that New Zealand standards of safety and employment were applied to all FCVs operating in the EEZ. Nowhere in the history of the Fisheries Act, nor in the report on the ministerial enquiry, has a regime based around the principles of port State jurisdiction been suggested. Using the reluctance of the Ministerial Enquiry to recommend outright mandatory reflagging as its foundation, the remainder of this paper assesses the legislative shortcomings of the regime for FCVs, assesses these within the context of port State jurisdiction.

\section{International law relevant to fishing vessels in the EEZ}

The failure of New Zealand to effectively monitor or enforce the standards expected of FCVs is due, at least in part, to inconsistencies between the New Zealand law applied to these vessels, and the international law which determines jurisdictional rights over foreign flagged vessels. This was found in the conflicting relationship between coastal and flag State jurisdiction. Prior to examining the previous, current, and possible alternative legal regimes of New Zealand regarding foreign fishing vessels operating in its EEZ, this section will briefly outline the applicable international law, including flag, coastal, and port State jurisdiction, within which any of these regimes would necessarily exist. International fisheries legislation, while pertaining to the subject matter of this paper, is relevant only insofar as it allows for the regulation of fishing vessels and their

\footnotetext{
${ }^{29}$ Swain et al, above $\mathrm{n} 4$, at 92

30 David Carter and Kate Wilkinson "Foreign charter vessels to be reflagged" (22 May 2012) Beehive.govt.nz http://www.beehive.govt.nz/release/foreign-charter-vessels-be-reflagged

${ }^{31}$ Brown, above $\mathrm{n} 8$, at 27
} 
crew. Laws regarding the catching, processing, and conservation of fish and other living resources are outside the scope of this paper.

\section{A UNCLOS and Coastal State jurisdiction over foreign vessels}

The areas in which the offences onboard the vessels in question occurred was predominantly outside of New Zealand ports or internal waters. The EEZ in particular, is the key maritime area of concern to this paper, being the only maritime zone in which foreign vessels are permitted to fish in New Zealand, and beyond which (in the high seas) New Zealand jurisdiction over the vessels would be entirely absent. ${ }^{32}$ However, as foreign fishing vessels traverse the maritime zones of New Zealand ports, the territorial sea, and the EEZ in the course of their operations, it is necessary to understand the jurisdictional rights of coastal States in these areas. Usefully, these rights are formally established in UNCLOS, with the exception of port State jurisdiction.

\section{The Exclusive Economic Zone}

The 200NM EEZ must certainly be the exemplar aspect of international maritime law in which the rights and responsibilities of coastal and flag States are in a fine balance. For the coastal State, UNCLOS provides certain sovereign rights through article 56, including: ${ }^{33}$

(a) sovereign rights for the purpose of exploring and exploiting, conserving and managing the natural resources, whether living or non-living, of the waters superjacent to the seabed and of the seabed and its subsoil, and with regard to other activities for the economic exploitation and exploration of the zone, such as the production of energy from the water, currents and winds.

In turn additional jurisdiction is provided to the coastal State in the following areas: ${ }^{34}$

(i) the establishment and use of artificial islands, installations and structures;

(ii) marine scientific research;

(iii) the protection and preservation of the marine environment;

The focus of this paper is only on those rights afforded to the coastal State relating to fisheries management. This extends to the establishment of an allowable catch, which can be exploited exclusively by the coastal State, ${ }^{35}$ with the provision that access to any catch

\footnotetext{
32 United Nations Convention on the Law of the Sea 1833 UNTS 3 (opened for signature 10 December 1982, entered into force 16 November 1994), Art 94

${ }^{33}$ UNCLOS Art 56.1(a)

${ }^{34}$ UNCLOS Art 56.1(b)(ii)

${ }^{35}$ UNCLOS Art 61
} 
beyond the capacity of the coastal State is afforded to foreign vessels, subject to certain regulations of the coastal State over these vessels. ${ }^{36}$ In practical terms, the obligation to allow foreign vessels fishing rights in the EEZ is a superficial one, as coastal States can simply determine the total allowable catch within their own industries capacity to exploit. That, coupled with the right of coastal States to determine the licensing of fishermen and vessels in the area, ${ }^{37}$ ensures total coastal State control over what fishing vessels are legally operating in the EEZ, and in turn, who is working on-board those vessels.

Unlike the territorial sea or internal waters of a State, where complete jurisdiction derived from territorial sovereignty is at times limited by international law, jurisdiction over the EEZ is conversely a limitation of the general freedoms of the high seas in favour of the coastal State. ${ }^{38}$ Regulation of the EEZ by the coastal State extends only as far as the sovereign rights of article 56, at which point the EEZ should be treated as the high seas. For foreign vessels operating in a coastal State's EEZ the high seas freedoms as laid down by UNCLOS are explicitly provided: ${ }^{39}$

1. In the exclusive economic zone, all States, whether coastal or land-locked, enjoy, subject to the relevant provisions of this Convention, the freedoms referred to in article 87 of navigation and overflight and of the laying of submarine cables and pipelines, and other internationally lawful uses of the sea related to these freedoms, such as those associated with the operation of ships, aircraft and submarine cables and pipelines, and compatible with the other provisions of this Convention.

2. Articles 88 to 115 and other pertinent rules of international law apply to the exclusive economic zone in so far as they are not incompatible with this Part.

Of special significance to this paper is Article 94 of UNCLOS, which establishes that flag States maintain 'jurisdiction over each ship flying its flag...in respect of administrative, technical and social matters. ${ }^{40}$ This includes jurisdiction over the labour conditions, construction and equipment of the vessel, ${ }^{41}$ provided such equipment and construction is not specifically related to the fishing industry. In short, while a coastal State may prohibit

\footnotetext{
${ }^{36}$ UNCLOS Art 62

${ }^{37}$ UNCLOS Art 62.4(a)

${ }^{38}$ Yoshifumi Tanaka The International Law of the Sea (Cambridge University Press, Cambridge, 2012), at 127.

${ }^{39}$ UNCLOS Art 58

${ }^{40}$ UNCLOS Art 94.2(b)

${ }^{41}$ UNCLOS Art 94.3
} 
vessels entering its EEZ to fish and take enforcement action where laws pertaining to the regulation of these fisheries, or protection of the environment, are infringed upon, the internal affairs of a ship remain under the jurisdiction of the flag State, even where approved fishing has commenced.

\section{The Territorial Sea}

The coastal State retains sovereignty over the territorial sea, subject to the rights of innocent passage, allowing foreign ships passage through the territorial sea of another State provided it is expeditious and continuous. The coastal State has legislative jurisdiction over several areas listed in UNCLOS which are exhaustive and inclusive, and to which foreign vessels are required to comply with while invoking the right of innocent passage. ${ }^{42}$ These areas include the following: ${ }^{43}$

(a) the safety of navigation and the regulation of maritime traffic;

(b) the protection of navigational aids and facilities and other facilities or installations;

(c) the protection of cables and pipelines;

(d) the conservation of the living resources of the sea;

(e) the prevention of infringement of the fisheries laws and regulations of the coastal State;

(f) the preservation of the environment of the coastal State and the prevention, reduction and control of pollution thereof;

(g) marine scientific research and hydrographic surveys;

(h) the prevention of infringement of the customs, fiscal, immigration or sanitary laws and regulations of the coastal State.

Therefore, except in special circumstances, the flag State retains jurisdiction over the vessels internal affairs while innocent passage occurs. Generally, passage ceases to be innocent when it involves an act against the coastal State itself, which impacts on the peace, good order, and security of that State. ${ }^{44}$ Furthermore, offences which have occurred outside of the territorial sea do not impact on the innocence of a ship's passage in that area, rather the offences have to take place during the passage itself. ${ }^{45}$ Accordingly, UNCLOS does not explicitly allow unlimited coastal State rights to regulate or enforce instances of crew abuse or employment conditions on-board foreign vessels

\footnotetext{
42 Anne Bardin “Coastal State’s jurisdiction over foreign vessels” (2002) 14 Pace Int'l L. Rev. 27 , at 36

${ }^{43}$ UNCLOS Art 21

${ }^{44}$ Haijiang Yang Jurisdiction of the Coastal State over Foreign Merchant Ships in Internal Waters and the Territorial Sea (Stringer International Publishing, Heidelberg, 2006), at 166-168

${ }^{45}$ Haijiang, above n 44, at 164
} 
within the territorial sea. While the coastal State has some jurisdiction over the design, construction, manning and equipment of vessels, this is limited to the application of internationally recognised standards. ${ }^{46}$ UNCLOS further extends the right of innocent passage to vessels transiting to and from ports, although importantly, as will be discussed later in this paper, this right should not be viewed as absolving a foreign vessel of the requirement to comply with entry and exit requirements of that port, as determined by the coastal State. $^{47}$

Criminal jurisdiction over the internal affairs of a foreign vessel can be applied in the territorial sea in some circumstances, but only where the offence was committed within the territorial sea and disturbs the good nature or peace of the State, the flag State or the ships master has requested assistance in the investigation and prosecution of a crime, or if the vessel is trafficking narcotic drugs. ${ }^{48}$ Given the limited events for which criminal jurisdiction is provided, and the importance of the location of the offence, it remains that under UNCLOS a coastal State has little recourse to address the issues occurring onboard foreign vessels which are the topic of this paper. The pursuance of civil cases is similarly limited by being allowable only against the ship rather than individuals onboard, and only for liabilities incurred in the course of that ships voyage through the territorial sea. ${ }^{49}$ In both criminal and civil jurisdiction, infringements which have occurred in the internal waters against local laws may be pursued and a ship arrested in the territorial sea. ${ }^{50}$

\section{B Extra-Territorial Jurisdiction}

It is clear then that Coastal States have a limited right to prescribe and enforce laws regarding offences which are the subject of this paper, where those offences take place in their territorial sea (subject to the provisions of innocent passage), and no clear jurisdiction within the EEZ. However, in certain instances extra-territorial legislation may be invoked which gives States the ability to address offences which have occurred throughout all maritime zones. Perhaps the most significant is jurisdiction derived from the 'effects' doctrine. The application of this principle can see a State apply its own laws to acts which occur outside of territorial jurisdiction, and which either are completed within the State's territory (objective territorial jurisdiction), or which have an adverse

\footnotetext{
${ }^{46}$ Haijiang, above $\mathrm{n} 44$, at 190

${ }^{47}$ Haijiang, above $\mathrm{n} 44$, at 151

${ }^{48}$ Bardin, above $n$ 42, at 37-38

${ }^{49}$ UNCLOS Art 28

${ }^{50}$ Bardin, above $n 42$, at 37-38
} 
effect on the State. Most commonly, this principle is cited in relation to the Lotus case, in which Turkish law was successfully applied to a foreign ship after it collided with a Turkish ship (the 'effect' against the State being on the ship itself), and interestingly, can extend to economic effects which do not strictly effect the State physically. ${ }^{51}$ Other applications of unilateral extra-territorial jurisdiction include the 'national' principle in which acts are committed by a State's citizen outside its territory; the 'protective' principle in which a State acts to protect its 'vital interests'; and the 'universal' principle in which the offence is a heinous crime such as genocide, or other conventionally mandated universal offences such as piracy. ${ }^{52}$

\section{International Conventions}

A more robust assertion of extra-territorial jurisdiction is found in the development of international conventions. These treaties will usually outline a range of offences, before outlining obligations for party States to enforce such offences, regardless of the nationality or location of the offender. Essentially, such measures provide universal jurisdiction for the offence, ${ }^{53}$ or practically speaking, serve as specific advance permission for a coastal State to act on a flag State's behalf. Notably, Article 218 of UNCLOS gives clear and limited provision for port States to exercise jurisdiction over vessels committing illegal discharges in areas beyond national jurisdiction, including the maritime zones of other States with that State's approval. ${ }^{54}$ Such provisions are exceptional in general international law, ${ }^{55}$ but are increasingly common in areas such as fisheries, vessel safety, and marine pollution through the development of international conventions. The nature of article 218 and these conventions is such that enforcement is taken against recognised international standards, rather than unilaterally applied local laws. For the most part, these 'internationally recognised standards' are seen to refer to the conventions developed by the International Maritime Organisation (IMO), and the International Labour Organisation (ILO).

Shipping standards developed through IMO conventions are routinely enforced by States within their ports against foreign vessel for offences over which they would normally not

\footnotetext{
$\overline{51}$ Vaughan Lowe and Christopher Staker "Jurisdiction" in Malcolm D. Evans (ed) International Law (3 $^{\text {rd }}$ ed, Oxford University Press, Oxford, 2010) 313, at 322

${ }^{52}$ Bevan Marten Port State Jurisdiction and the Regulation of International Merchant Shipping (Stringer International Publishing, Heidelberg, 2014), at 10

${ }^{53}$ Lowe and Staker, above $\mathrm{n} 51$, at 328

${ }^{54}$ UNCLOS, Art 218.

${ }^{55}$ Ted. L. McDorman "Port State Enforcement: A Comment on Article 218 of the 1982 Law of the Sea Convention" (1997) 28 J. Mar. L. \& Com. 305, at 318-319.
} 
claim jurisdiction, with authority for enforcement often being derived through Port State Control agreements. ${ }^{56}$ The International Convention for the Safety of Life at Sea (SOLAS), as an example, dictates minimum construction and equipment standards for vessel safety which, by their nature, are both under the jurisdiction of the flag State. The recently developed Agreement on Port State Measures to Prevent, Deter, and Eliminate Illegal, Unreported and Unregulated Fishing (PSM Agreement) further seeks to clarify the right for port States to exercise extraterritorial jurisdiction over high seas fishing by having States incorporate measures into national legislation to aid fisheries conservation through port State measures, including inspection, and denial of entry to ports. ${ }^{57}$

Several points are of note here. The first is that administrative matters, labour conditions, and vessel safety on-board fishing vessels is an area of international law which is either omitted from otherwise relevant conventions, or are without specifically targeted conventions in force or existence. ${ }^{58}$ Both SOLAS, ${ }^{59}$ and the Maritime Labour Convention, ${ }^{60}$ which establishes standards for the fair, safe and equitable treatment of merchant seafarers, expressly exclude fishing vessels from their application. Conventions specific to labour and safety conditions on fishing vessels, the Torremolinos Protocol, ${ }^{61}$ and the International Labour Organization's C188 - Working in Fishing Convention 2007, ${ }^{62}$ have not yet received sufficient ratification to enter into force. With reference to the latter, this places responsibility for setting and enforcement of standards with the flag State, with a coastal or port State roles limited to verifying compliance with flag State requirements. ${ }^{63}$ The exception to this is the International Convention on Standards of Training, Certification and Watchkeeping for Fishing Vessel Personnel

\footnotetext{
${ }^{56}$ Marten, above $n$ 52, at 46-53.

${ }^{57}$ Blaise Kuemlangan and Michael Press, "Preventing, Deterring and Eliminating IUU Fishing - Port State Measures" (2010) 40 Envt'l Pol'y \& L.262, at 264-266

${ }^{58}$ Camille Goodman "The Regime for Flag State Responsibility in International Fisheries Law - Effective Fact, Creative Fiction, or Further Work Required?' (2009) 23 Austl. \& N.Z. L.J. 157, at 161

${ }^{59}$ International Convention for the Safety of Life at Sea 1184 UNTS 3 (opened for signature 1 November 1974, entered into force 25 May 1980), Reg 3

${ }^{60}$ Maritime Labour Covention (opened for signature 23 February 2006, entered into force 20 August 2012). Art II. 4

61 "Status of Conventions" (31 August 2014), International Maritime Organisation http://www.imo.org/About/Conventions/StatusOfConventions/Pages/Default.aspx

62 "Ratifications of C188 - Work in Fishing Convention, 2007 (No. 188)" International Labour Organisation http://www.ilo.org/dyn/normlex/en/f?p=1000:11300:0::NO:11300:P11300_INSTRUMENT_ID:31 2333

${ }^{63}$ Marten, above n 52, at 168
} 
(STCW-F) which came into force in 2012. This convention sets standards for training and certification of crews of fishing vessels, but at the time of writing has yet to be ratified by New Zealand or the majority of flag States operating FCVs in the EEZ. ${ }^{64}$

The second note is on the role of Port State Control. Port State Control, initially developed through the Paris MOU, regulates the in port inspection and detention of substandard vessels against international conventions, and has been described by Hare as 'the most effective means of ridding the world's ports and oceans of sub-standard, unseaworthy and dangerous ships. ${ }^{65}$ Comment on it is included here for completeness only, as given the State of international fishing vessel conventions, and the exclusion of these from the Memorandum of Understanding on Port State Control in the Asia-Pacific Region (Tokyo MOU), ${ }^{66}$ to which New Zealand is party, it offers no ability in itself for New Zealand to regulate FCVs. Rather, the in port enforcement of matters relating to vessel standards by New Zealand in relation to FCVs would effectively occur as a unilateral application of port State control measures.

\section{Port State Jurisdiction}

The maritime zone in which the least ambiguity regarding coastal State jurisdiction over foreign vessels exists is the ports and internal waters of a State. Port State jurisdiction is derived from general international law, ${ }^{67}$ rather than UNCLOS which is largely silent on the matter. Nonetheless, ports are sometimes thought as expressed in UNCLOS, as including anything within 'the outermost permanent harbour work which form an integral part of the harbour system,' which are regarded as forming part of the coastline. ${ }^{68}$ Such an interpretation brings ports within the territorial jurisdiction of the internal waters, over which UNCLOS (or any other general international law) offers no limitations. However, as Marten points out, the location of a port either within or outside of the internal waters of a State is inconsequential, given that in voluntarily stopping at a port a vessel waives

\footnotetext{
64 "Status of Conventions" (31 August 2014), International Maritime Organisation http://www.imo.org/About/Conventions/StatusOfConventions/Pages/Default.aspx. The notable exception to this is the Ukraine

${ }^{65}$ John Hare "Port State Control: Strong Medicine to Cure a Sick Industry" (1996-1997) 26 Ga. J. Int'l \& Comp. L. 571, at 594

${ }^{66}$ Memorandum of Understanding on Port State Control in the Asia-Pacific Region (Tokyo MoU) (adopted 1 December 1993), s 2

${ }^{67}$ Erik Jaap Molenaar "Port State Jurisdiction: Towards Comprehensive, Mandatory and Global Coverage" (2007) 38 ODILA 225, at 232

${ }^{68}$ UNCLOS Art 29
} 
the right of innocent passage, and comes under the full and unlimited jurisdiction of the coastal State. ${ }^{69}$

For the purposes of this paper Marten's definition of a 'port' will be utilised, referring to places within the territorial sea 'where vessels are loaded and unloaded, and which form a convenient point at which to exercise control over vessels which have voluntarily stopped there for a visit,' including 'roadsteads, mooring buoys... and other areas falling outside the classic "wharves within a natural harbour" incarnation of a port. ${ }^{70}$ Respectively, the 'port State' refers to the State which holds jurisdiction over these places. Having established the definition of a port, the scope of port State jurisdiction can be summed as follows: ${ }^{.71}$

"Once a ship voluntarily enters port it becomes fully subject to the laws and regulations prescribed by the officials of that territory...and are in common expectation obliged to comply with the coastal regulations about proper procedures to be employed and permissible activities within internal waters."

In short, whilst in a port a foreign vessel is subject to the full territorial jurisdiction of that State, and therefore 'the coastal State may take any measures and acts to exercise its jurisdiction as long as they are not prohibited by applicable international law, ${ }^{72}$ the most notable limitation being the restriction of environmental enforcement to international rules and standards found in Article 218 of UNCLOS.

\section{Port Access}

Despite various authors having previously argued that the right of navigation affords ships entry to port, or that international law requires ports to be open for trade, ${ }^{73}$ it is appears to be generally accepted now that there is no formal or customary international law which requires States to open their ports. Indeed, States 'in the exercise of their sovereignty, have the right to grant access, subject to conventional obligations and to an exception for vessels in distress. ${ }^{74}$ The only limitation of this is imposed by Article 211 of UNCLOS, which aligns entry requirements to internationally recognised rules. ${ }^{75}$

\footnotetext{
${ }^{69}$ Marten, above $\mathrm{n} 52$, at 22

${ }^{70}$ Marten, above n 52, at 21

${ }^{71}$ Hare, above $\mathrm{n} 65$, at 572

${ }^{72}$ Haijiang, above $\mathrm{n} 44$, at 42

${ }^{73}$ Louise de La Fayette "Access to Ports in International Law" (1996) 11 Int'l J Marine \& Coastal L 1, at $18-21$

${ }^{74}$ De La Fayette, above n 73, at 11

${ }^{75}$ UNCLOS Art 211
} 
Therefore, with the exceptions of the environmental limitations noted in UNCLOS for entry requirements, in exercising the right to grant access to any vessel, States generally have the right to impose any entry requirements for their ports that they see fit. When coupled with the territorial jurisdiction detailed above, in effect ports can introduce regulations on vessels entering their ports, provided that enforcement only occurs in the port itself. ${ }^{76}$ The enforcement of these prescribed regulations will be discussed later in this paper.

\section{Vessels in distress}

The right for vessels in distress to seek refuge is a customary one which can be traced back to the earliest days of maritime trade. ${ }^{77}$ UNCLOS allows for ships exercising the right of innocent passage to take refuge within the territorial waters of another State for reasons of force majeure, where those vessels would otherwise need to be in transit. ${ }^{78}$ Contemporary customary international law regarding entry into the ports and internal waters of a State in no ways guarantees entry into those waters for vessels in distress, and the custom is now largely seen as a humanitarian one, rather than one which requires the admission of the vessel itself to port. ${ }^{79}$ However, in cases of vessel entry due to distress, consensus holds that the enforcement of local laws and regulations should be restrained, ${ }^{80}$ with the expectation being that the vessel will sail once it is fit to ${ }^{81}$ Despite this, as FCVs operating within New Zealand waters are required to transit to and from New Zealand ports on a regular basis, the limitation of port State control is largely inconsequential to the arguments of this paper.

\section{Criminal and civil jurisdiction}

International law holds no limitations on the prescriptive jurisdiction of a State of its criminal laws to foreign ships within its ports and internal waters, and State practice suggests that enforcement jurisdiction (on which international law offers no opinion), is also within the remit of the coastal State in these areas. ${ }^{82}$ Despite this, actual enforcement

\footnotetext{
${ }^{76}$ Marten, above $\mathrm{n}$ 52, at 101

${ }^{77}$ Aldo Chircop "The Customary Law of Refuge for Ships in Distress" in Aldo Chircop and Olof Linden (ed) Places of Refuge for Ships: Emerging Environmental Concerns of a Maritime Custom (Martinus Nijhoff Pulishers, Leiden, 2006) 163, at 170

${ }^{78}$ UNCLOS, Art 18(2)

${ }^{79}$ Chircop, above n 77, at 222-223

${ }^{80}$ Christopher F. Murray "Any Port in a Storm? The Right of Entry for Reasons of Force Majeure or Distress in the Wake of the Erika and Castor" (2002) 63 Ohio St. L. J. 1465, at 1473

${ }^{81}$ Murray, above $\mathrm{n} 80$, at 1476

${ }^{82}$ Haijiang, above $\mathrm{n} 44$, at 93
} 
against foreign ships is rare and at best restrictive, and as the duel jurisdictions of flag and coastal State remain in such instances, custom holds that these need to be acknowledged.

Alternatively, the application of a coastal State's civil laws is somewhat more problematic. Nothing limits the coastal State in being able to prescribe civil jurisdiction over the foreign vessel, and for disputes to be heard in its courts. However, the interpretation and regulation of nuances contained within any agreements involving those on-board, as well as any potential conflicts of law, may be left to the discretion of the court involved in choosing to apply domestic statues, and therefore does not necessarily automatically favour the coastal State's laws as with the penal code. ${ }^{83}$ In the case of employment agreements for workers on foreign vessels operating within a coastal State's waters, the common law principles favouring the 'closest and most real connection' of the agreement to the system of law which governs it including where the employer is based, the residence or domicile of the employee, and the language and form of the contract, weigh strongly against the coastal State. ${ }^{84}$

While the coastal State retains prescriptive and enforcement jurisdiction of civil and criminal law, such laws may be subject to pressure due to what is generally referred to as the 'internal effects' principle. This principle suggests that even while in port, the internal affairs of a vessel, that is, crimes or disputes relating to those on board (for example, between crew members) should be left to the flag State for resolution. The application of local laws and regulations should equally be left to occasions where the offence is disruptive to the peace and tranquillity of the port. Whether this is a matter of customary international law, or comity, as French or Anglo-American jurisprudence would hold respectively, is a matter of some debate. ${ }^{85}$ The French interpretation suggests that matters including employment contracts and labour protection go beyond the jurisdiction of the coastal State, regardless of the vessels location with a port, while the Anglo-American interpretation holds this as a matter of comity. ${ }^{86}$ For the purposes of this paper, the latter interpretation is favoured by this author. Therefore, it should be viewed that while States may choose and favour the limitation of the application of their laws when the internal affairs of a vessel are in question, the State also retains the right to exercise complete jurisdiction should it see fit to.

\footnotetext{
${ }^{83}$ Haijiang, above $\mathrm{n} 44$, at 95

${ }^{84}$ Haijiang, above $\mathrm{n} 44$, at 84

${ }^{85}$ Marten, above $\mathrm{n} 52$, at 30

${ }^{86}$ Haijiang, above $n$ 44, at 91
} 


\section{E Summary of section}

The existing international law regarding jurisdiction over foreign vessels by coastal States demonstrates that, while the regulation of environmental and economic matters is clear, as is the inclusion of navigational safety if in relation to the territorial sea, the ability to address matters regarding the 'internal affairs' of a vessel is severely limited. Furthermore, while some ability to enforce standards of vessel construction, design and equipment may exist, this is generally against internationally recognised standards, little of which exists for fishing vessels. On the other hand, the ability for the coastal State to regulate these matters increases significantly if addressed through port State jurisdiction, subject to some limitations, including that the vessel is in port on a voluntary basis.

Referring back to the sections above, a full understanding of where the offence the coastal State wishes to regulate, and the place in which it enforces this, is essential if the territorial sovereignty of the port is being exercised. As Marten States, 'where port State jurisdiction is concerned, the intention is to have any necessary enforcement action take place in port, and thus within the State's territory. ${ }^{97}$ Likewise, unless the principles of extra-territorial jurisdiction outlined above are applicable, port State jurisdiction relies on the offence or infringement occurring within the State's territory. Whether the offences on-board FCVs could have been regulated in such a way will be explored in the final section of this paper. The following sections will explore the misalignment of the regime for regulating FCVs within the context of international law detailed above, and how these faults were rectified by the Fisheries Amendment Act.

\section{The legal regimes for FCVs pre and post-2014}

As noted above, the regulation of FCVs within New Zealand waters has been subject to various changes since the ascension of the Fisheries Act in the mid-1990s. These changes have been occasioned by, and sought to solve, the ongoing reports of abuse with the fishing industry. Rather than removing FCVs from the judicial picture as the Fisheries Amendment Act would ultimately do, these earlier changes sought to apply New Zealand law to foreign vessels and their crew. Most notably, this included the extension of the Minimum Wage Act and the Wages Protection Act to workers onboard FCVs in the late $1990 \mathrm{~s},{ }^{88}$ and in 2006 the introduction of a Code of Practice for New Zealand Charter Parties. ${ }^{89}$ The Code of Practice and the protection of employee wages sought to apply

\footnotetext{
${ }^{87}$ Marten, above $\mathrm{n} 52$, at 8

${ }^{88}$ Delvin, above $\mathrm{n} 22$, at 85

${ }^{89}$ Dawson and Hunt, above n 6, at 198
} 
New Zealand working conditions and employment agreements to FCVs through the use of prerequisites for both registrations of fishing vessels, and the issuing of work visas to fishing crews. The Code of Practice also placed the responsibility for compliance with these requirements onto the New Zealand Charter Parties. Despite their intentions, these measures proved ineffective in properly managing working conditions onboard FCVs, largely due to their relationship to the international law detailed above.

This section will provide a general outline of the use of FCVs under the Fisheries Act, as well as the changes brought by the Fisheries Amendment Act, establishing the legislative framework in which these regimes operate. The sections which follow will address the legislative requirements for FCVs as broken down into specific aspects of New Zealand law as it pertains to the types of reported infringements onboard the vessels; those being vessel safety, employment agreements and wages, and abuse. Each section will give a specific overview of the law for the subject matter pre and post the Amendment Act. Finally, by examining the law and existing State practice, each section will conclude by exploring whether the intended outcomes of Amendment Act could have been achieved, with the retention of FCVs, through the application of port State jurisdiction.

\section{A Foreign Charter Vessels under the Fisheries Act 1996}

The principle New Zealand legislation governing the use of FCVs in New Zealand waters is found in section 103 of the Fisheries Act. Attention is sometimes also drawn to Part 5, specifically the calculation and allocation of a foreign allowable catch. This section of the Act is included to distinguish between the fulfilment by New Zealand of its obligations under UNCLOS to allocate its surplus total allowable catch (TAC) to other nations, ${ }^{90}$ and the use of FCVs to provide New Zealand the capacity to fully harvest its TAC. While some NZCPs have argued that the use of FCVs to fulfil the obligations of article 62 of the Convention, this argument is erroneous, and is a misinterpretation of the provision of UNCLOS which requires access to surplus fisheries for other States, not for other States to assist in the coastal State's exploitation of its own allocation. ${ }^{91}$ This section therefore concentrates solely on section 103 of the Act, and the associated legislation and regulation.

While the workings of the quota management system are outside of the scope of this paper, an overview as to how FCVs fit within this system is of value. Under the Fisheries Act, the TAC is typically allocated to New Zealand quota holders, while foreign investors

${ }^{90}$ UNCLOS, Art 62.

${ }^{91}$ Dawson and Hunt, above n 6, at 201 
require Ministerial approval. The quota, which is tradable and exists in perpetuity, entitles the owner to a fixed quantum of catch from a particular fish stock. Ownership of quota is also subject to the terms of Crown settlement against the Treaty of Waitangi. Under these terms, Maori are allocated 20 percent of quota for any given fish stock introduced into the QMS. ${ }^{92}$ The chartering of FCVs under section 103 of the Act is an undertaking in which a New Zealand Charter Party charters a vessel in order to exploit their quota holding. FCVs are deep water fishing vessels which operate within the QMS as it pertains to the EEZ, and are not permitted to fish within the $12 \mathrm{NM}$ territorial sea. ${ }^{93}$

Section 103 of the Act imposes a number of requirements on fishing vessels wishing to operate in New Zealand waters. These include first that the vessel be registered in the Fishing Vessel Register as a fishing vessel. ${ }^{94}$ Under Section 103, the registration of the vessel is to include the name of the operator, who must also be the person to apply to the Chief Executive of the governing Ministry (previously the Ministry of Agriculture and Forestry, and now the Ministry of Primary Industries), for approval to register the vessel. The allowance for the use of FCVs in New Zealand fisheries (until 2016) and the application of the Act and other relevant provisions on them is found in subsections 4, which read: ${ }^{95}$

(4) No vessel owned or operated by an overseas person (other than an overseas person who has obtained consent under the overseas investment fishing provisions or is exempt from the requirement for that consent) shall be registered under this section unless the chief executive has consented, either generally or particularly, to the registration of the vessel or vessels owned or operated by that person; and any consent under this subsection may be granted subject to such conditions as the chief executive thinks fit to impose.

The Act provided no limitations as to the nature of the charter agreements being entered into, a point which would later be challenged by the Ministerial Enquiry into the matter. However, as Stated above, the use of a charter vessel could therefore take place under either a time or a demise charter, the former seeing the operator remaining in control of the vessel and employing the crew, the latter seeing the ship provided to the New Zealand

\footnotetext{
${ }^{92}$ Swain et al, above $\mathrm{n} 4$, at 18

${ }^{93}$ Fisheries Act 1996 s 113

${ }^{94}$ Fisheries Act 1996 s 103

${ }^{95}$ Fisheries Act 1996 s 103(4)
} 
charter party without crew or master. As of 2012, only a single FCV was operating under a demise charter arrangement. ${ }^{96}$

Subsection 5 goes on to State that following approval of its registration, any vessel is required to comply with a number of provisions laid down in the Act whilst operating in New Zealand waters. The provisions which follow establish requirements for minimum wages, the jurisdiction of New Zealand employment courts and tribunals to hear any disputes arising on-board the vessels, and the authority of New Zealand labour inspectors to inspect vessels registered under Section 103. In addition to the Fisheries Act, and by virtue of the need to register the vessel under section 103, a number of Maritime Rules are seen to apply to FCVs.

Additionally, the aforementioned Code of Practice developed in 2006, sought to strengthen the wage protection provision of section 103 of the Act, while also addressing issues relating to labour conditions and abuse not already covered by the Act. The Code of Practice was itself a product of an investigation into practices on-board the FCV fleet in New Zealand fisheries, which highlighted a number of concerns similar to those detailed in the first section of this paper. The Code was required to be entered into with the Department of Labour, by all New Zealand parties to FCV charter arrangements, with agreement to the terms of the Code required prior to the issuance of visas for crew to work on-board those vessels. ${ }^{97}$ In addition to protecting the rights and safety of foreign crew members on board FCVs, the Code additionally sought to prevent immigration infringements caused by FCV crew members fleeing their vessels. The strengths and weaknesses of the legislative provisions, and those of the Code of Practice, are explored in more detail below.

\section{B The Fisheries Amendment Act - Immediate Changes}

Immediate changes to the Fisheries Act give additional powers to the Chief Executive of the Ministry of Primary Industry to suspend, or impose conditions on, the registration of any high seas fishing vessel, relating to fisheries management, vessel safety, employment and compliance with Maritime Rules relating to environmental protection. ${ }^{98}$ The Chief Executive has the ability to extend the period of this suspension where he has reason to believe that the conditions imposed have not been complied with. Additionally, the role

\footnotetext{
${ }^{96}$ Dawson, Peter "Foreign Charter Vessels: A Confused Legal Regime” (Presentation to MLAANZ - NZ Branch Conference, Hilton, Taupo, 27 April 2012), at 6

${ }^{97}$ Delvin, above n 22, at 88-89

${ }^{98}$ Fisheries (Foreign Charter Vessels and Other Matters) Amendment Act 2014, s 4(3)
} 
of observers on board the vessels is extended to expressly include the collection of information regarding 'statutory responsibilities for vessel safety, employment matters, or maritime rules relating to pollution and the discharge of waste material from vessels. 99 Included in this is the right of access of any observer to safety equipment on board, as well as to any person employed or engaged on-board, allowing discussion on any aspect of their employment or engagement on the vessel. ${ }^{100}$

These changes were originally recommended by the Ministerial Enquiry which followed the publicity around the conditions on board FCVs. ${ }^{101}$ In addition to the clarification of the role of observers on board, the Ministry of Primary Industries also indicted that it would work to place an observer on all FCVs operating in New Zealand waters, ${ }^{102}$ up from thirty percent in 2010/11. ${ }^{103}$ Essentially, these amendments provide for additional monitoring of the extant regulatory regime during the phase leading up to the requirement for vessels to be New Zealand ships; however they do little to address the fundamental concerns of jurisdiction which motivated the requirement for registration of fishing vessels to New Zealand. Beyond the legal regime for FCVs prior to the Amendment Act, greater enforcement of the regimes requirements in these amendments is addressed through the removal off an offending vessel's right to fish in the EEZ, rather than over specific acts which occur on the vessel.

\section{The Fisheries Amendment Act-Reflagging Fishing Vessels}

Essentially, the intention and significance of the Amendment Act in brought into effect through the inclusion of the following paragraph into section 103 of the Act, effective from 1 May 2016: ${ }^{104}$

"(1) A person must not use a fishing vessel, or any tender of that fishing vessel, to take fish, aquatic life, or seaweed for sale, in New Zealand fisheries waters, unless-

(a) the vessel is a New Zealand ship or has been exempted under section 103A(1) from that requirement;"

The exemptions referred to in the section of the Act quoted above refer to vessels which are being used for marine scientific research purposes only, of which the risk of the

\footnotetext{
${ }^{99}$ Fisheries (Foreign Charter Vessels and Other Matters) Amendment Act 2014, s 11(2)

${ }^{100}$ Fisheries (Foreign Charter Vessels and Other Matters) Amendment Act 2014, s 11(2)

101 Swain et al, above n 4, at 83-88

102 Brown, above $\mathrm{n} 8$, at 39

${ }^{103}$ Swain et al, above $\mathrm{n} 4$, at 61

${ }^{104}$ Fisheries (Foreign Charter Vessels and Other Matters) Amendment Act 2014
} 
offending detailed is this paper was seen as sufficiently low for inclusion in the Act. Suggestions for additional exemptions were rejected while the bill was before parliament. $^{105}$

A 'New Zealand ship' is defined as a ship registered, or entitled to be registered, under the Ship Registration Act 1992. ${ }^{106}$ Under the Ship Registration Act, a ship assumes the nationality of New Zealand, and is entitled to fly its flag, ${ }^{107}$ and is also strictly prohibited from being registered under the laws of a foreign country. ${ }^{108}$ In requiring that all fishing vessels operating within New Zealand waters are New Zealand ship, the Amendment Act therefore removes any ambiguity regarding jurisdiction which resulted from the use of foreign flagged vessels.

In ensuring that vessels operating in New Zealand fisheries are flagged to New Zealand, the amendment act has a dramatic impact on the applicable laws not only to the vessels construction, design, and equipment, but also on its internal affairs, including employment relations, and crimes including abuse. Importantly for this paper the Amendment Act brings into force against the fishing vessels in the EEZ the Health and Safety in Employment Act 1992, the Crimes Act 1961, and the Maritime Transport Act 1994. As established in the preceding section, this jurisdiction is unequivocally in conformity with the international law of the EEZ, as defined by UNCLOS.

\section{The effect of the changes on the fishing industry in New Zealand}

The economic argument for allowing FCVs access to New Zealand fisheries is worth noting here. This argument broadly exists at two levels; the economic benefit to New Zealand as a whole, and; the economic benefit to individual quota holders in New Zealand. At a high level, the economic contribution FCVs make to the New Zealand fishing industry is very significant. In 2011, New Zealand's seafood exports were its fourth largest export earner, with a total value to New Zealand of $\$ 658$ million. ${ }^{109}$ In the same year, $44 \%$ of these exports were of catch taken by FCVs. ${ }^{110}$

For individual quota holders, the capital investment needed to comply with the requirement to use only New Zealand ships was noted by several smaller companies

\footnotetext{
105 (30 July 2014) 700 NZPD 19655

106 Ship Registration Act 1992, s 2 (1)

107 Ship Registration Act 1992, s 57

108 Ship Registration Act 1992, s 9

${ }^{109}$ Swain et al, above $n$ 4, at 53

${ }^{110}$ Dawson, above n 96, at 3
} 
during the Ministerial Enquiry. Costs of vessel replacements were noted as being prohibitive for some operators, with costs determined at \$35-45 million, ${ }^{111}$ enough for some to foresee the closure of certain fisheries to New Zealand quota holders. ${ }^{112}$ The capacity FCVs add to the New Zealand industry was also noted. For example, in their submission to the Select Committee on the Fisheries Amendment Bill, Sealord Ltd. noted that the significant majority of low value fish stocks are caught by FCVs, ${ }^{113}$ while Sanford made similar reference to seasonal fish stocks and the specialist equipment required to catch these which was unavailable unless through FCVs. ${ }^{114}$ The potential for the value of quota holdings to be reduced following the increased costs of catching and processing fish was another noted impact on individual New Zealand quota holders. ${ }^{115}$

The most significant impact of the requirement to reflag fishing vessels to New Zealand will be on Maori quota holders, who collectively own $40 \%$ of all high seas quota and employ FCVs to exploit $80 \%$ of their holdings. ${ }^{116}$ Challenges to the requirement to reflag vessels to New Zealand has been impassioned on this ground, with one iwi spokesperson going as far as to claim that "not a single iwi could afford to buy a ship... it will become uneconomic for a lot of the smaller iwi to even open an office to be involved in fishing.' 117 The significance of Maori interests was such that when the bill was returned from the Select Committee, an exception to mandatory vessel registration was included which could allow FCVs to be used being used to exploit a Treaty settlement quota that represented a significant proportion of all annual catch entitlement held by that operator. ${ }^{118}$ Ultimately this exception was dropped from the bill.

Verifying the accuracy of likely economic impacts is a complex issue, made more difficult by the limited information available regarding operating costs for New Zealand

${ }^{111}$ Auroha Fisheries Limited "Submission to the Primary Production Committee on the Fisheries (Foreign Charter Vessels and Other Matters) Amendment Bill 2012" at 3

${ }^{112}$ Maruha (N.Z.) Corporation Limited "Submission to the Primary Production Committee on the Fisheries (Foreign Charter Vessels and Other Matters) Amendment Bill 2012” at 2

113 Sealord Group Limited "Submission to the Primary Production Committee on the Fisheries (Foreign Charter Vessels and Other Matters) Amendment Bill 2012" at 4

114 Sanford Limited "Submission to the Primary Production Committee on the Fisheries (Foreign Charter Vessels and Other Matters) Amendment Bill 2012" at 7

115 Yvonne Tahana "Maori quota holders sidestep foreign-worker law: Where they come from" New Zealand Herald (Auckland, New Zealand, 27 July 2013)

116 Dawson and Hunt, above n 6, at 197

117 Tahana, above n 115

${ }^{118}$ Primary Production Committee Fisheries (Foreign Charter Vessels and Other Matters) Amendment Bill (25 July 2013), at 10 
quota holders. As such, it is beyond the scope of this paper. However, it should be recognized in the exceptions originally intended for the bill, and in the findings of the Ministerial Enquiry, that a not insignificant economic interest exists for continued use of FCVs, albeit one that was outweighed by the ineffective legal regime governing their use. The remainder of this paper assesses whether such a regime could have been developed through port State jurisdiction.

\section{$V$ Bringing FCVs to port}

The effective use of port State jurisdiction to regulate foreign fishing vessels within New Zealand waters would require that those vessels enter voluntarily into New Zealand ports on a regular basis. Regarding fishing vessels this is, legally and practically speaking, a matter of little difficulty. Practically speaking, FCVs operating in the EEZ largely base themselves within New Zealand, rarely making voyages overseas. ${ }^{119}$ Legally speaking, the Fisheries Act requires that all resources caught within the EEZ be landed in New Zealand. ${ }^{120}$ In practice, this is enforced through mandatory catch inspections undertaken by inspectors of the Ministry of Primary Industries, inspections which on the whole occur within a New Zealand port. As such, the right for any vessel, foreign or domestic, to fish New Zealand waters requires it enter a New Zealand port on a regular basis. This requirement is consistent with international law, and is explicitly provided for in article 64 of UNCLOS, which states that among other requirements, a coast State can require 'the landing of all or any part of the catch by foreign [sic] vessels in the ports of the coastal State. ${ }^{121}$

It is clear that any vessel entering the ports of a coastal State in fulfilment of such a requirement has not entered that port for reasons of force majeure or distress. The discussion on international law provided above further makes clear that unless FCVs are transiting from a port facility to the EEZ (whether to fish or not), the right of innocent passage could not be invoked. Therefore in such instances, the vessel would be subject to the full prescriptive and enforcement jurisdiction of the port State. The difficulties of applying New Zealand law through port State jurisdiction is either in the establishment of legitimate extra-territorial jurisdiction to allow for the enforcement in port of offences in

\footnotetext{
${ }^{119}$ Primary Production Committee Fisheries (Foreign Charter Vessels and Other Matters) Amendment Bill (25 July 2013), at 3

${ }^{120}$ Fisheries Act 1996 s110

${ }^{121}$ UNCLOS Art 64.a(h)
} 
the EEZ, or the enforcement of offences in such a way as they are seen to have occurred within the port.

\section{Construction, Design, and Equipment standards}

\section{A The regime for FCV safety, pre-2014}

At the time of the Enquiry, vessel safety standards were applied to the applicable ships through the Safe Ship Management (SSM) regulatory framework of Maritime New Zealand, as found in Maritime Rule Part 21. The ability for New Zealand to regulate FCVs and any other foreign vessel operating in New Zealand waters in this way is found in section 34 of the Maritime Transport Act 1996, which provides for the creation of Maritime Rules which require an applicable maritime document to be held by a vessel. The requirements, standards, and application procedures for each document are in turn prescribed by the applicable rule. ${ }^{122}$ Maritime Rule Part 21 required that all ships operating under section 103 of the Fisheries Act held a Safe ship Management Certificate, which in turn demonstrated both compliance with the relevant rules and regulations of Maritime New Zealand, including the certification of crew and the provision of equipment, as well as compliance with a maintenance and inspection regime including audit and survey at regular intervals. ${ }^{123}$ The development of a safety and environmental policy of which all crew are familiar was also a requirement. ${ }^{124}$ Nonconformity with the Rule would result in the suspension of the certificate, and detention of the vessel or the issuing of a fine.

Maritime Rule Part 21 placed the onus on the owner of the vessel to comply with the applicable rules. From 2006 and the implementation of the Code of Practice, the New Zealand Charter Party became responsible for ensuring a foreign fishing vessel complied with both flag State safety standards as well as 'any applicable safety, marine protection, crew living and hygiene standards required by the Director of Maritime New Zealand.'125 As with all provisions of the Code of Practice, assurance of this provision was required prior to the approval in principle of working visas for FCV crew. That Maritime New Zealand held that it had the jurisdiction to enforce New Zealand safety standards onboard

\footnotetext{
122 Maritime Transport Act 1994, s 34

${ }^{123}$ Maritime Rule Part 21 Safe Ship Management Systems Appendix 1 cl 10

${ }^{124}$ Maritime Rule Part 21 Safe Ship Management Systems Appendix $1 \mathrm{cl} 7$

125 Department of Labour, Seafood Industry Council and New Zealand Fishing Industry Guild Inc Code of Practice on Foreign Fishing Crew (19 October 2006), at 9
} 
FCVs, ${ }^{126}$ is inherent in the Code's wording, that of 'any applicable' standards of the Director of Maritime New Zealand. However, alternate opinions held that jurisdiction was ambiguous at best, and the prescription of such standards lay with the flag State of a vessel. $^{127}$

The Ministerial Enquiry into FCVs, while not commenting on the jurisdiction of New Zealand to apply such rules, took issue with the wording of Maritime Rules which did not extend to foreign fishing vessels, particularly regarding Maritime Rule Part 31C, which set standards for crew qualifications. ${ }^{128}$ This aside, the setting of construction, design and equipment standards, developed in conformity with the Protocol to the Torremolinos Conventions (despite the lack of ratification by New Zealand), was extended to foreign vessels. $^{129}$

\section{B Through the use of Port State Jurisdiction}

While the full scope of Maritime Rules will be applied to fishing vessels from 2016 by virtue of their status as New Zealand ships, little will change in the prescriptive or enforcement jurisdiction of New Zealand authorities to regulate safety standards for fishing vessels operating under section 103 of the Fisheries Act. The practical effectiveness, or lack thereof, of the application of New Zealand safety standards to FCVs prior to the Amendment Act, can be illustrated in the level of compliance documented through the detainment in port of those vessels. That the issue of safety standards was one of policy and not legislation is recognized in the increase of FCVs detained (nine in 2011, compared to 2 total for the previous five years), ${ }^{130}$ demonstrating the increased standard of inspection following the highly publicized cases of abuse. Furthermore, of those detained vessels, the majority subsequently invested sufficiently to bring the vessel into compliance with New Zealand requirements without major protest. ${ }^{131}$ However, given that New Zealand is applying these standards to foreign vessels of States who are not party to the relative international conventions, ${ }^{132}$ and the uncertainty some commentators held regarding the jurisdiction of New Zealand to do this under international law

\footnotetext{
${ }^{126}$ Swain et al, above $\mathrm{n} 4$, at 71

${ }^{127}$ Dawson and Hunt, above $\mathrm{n}$ 6, at 209

${ }^{128}$ Swain et al, above $\mathrm{n} 4$, at 71

${ }^{129}$ Maritime Rule Part 40D

${ }^{130}$ Swain et al, above $\mathrm{n} 4$, at 69

${ }^{131}$ Swain et al, above $\mathrm{n} 4$, at 69

132 "Status of Conventions" (31 August 2014), International Maritime Organisation http://www.imo.org/About/Conventions/StatusOfConventions/Pages/Default.aspx
} 
(particularly UNCLOS), a comment on port State jurisdiction may be provided to clarify this jurisdiction.

State practice in unilaterally applying vessels standards or applying these beyond what is required by international conventions is far from unprecedented, the most famous of which is the requirement for tankers to be double-hulled when entering United States and European Union ports, but also in the provision of the Netherland's Foreign Ship Act to prescribe standards more stringent to those provided by the IMO. ${ }^{133}$ More recent State practice on the prescription of vessel standards can be found in the United States' Cruise Vessels Safety and Security Act 2010 (“Cruise Vessel Safety Act”), which among other things requires a handrail at a height higher than that of the relevant international convention, and the installation of peep-holes, door locks and camera surveillance systems on foreign flagged cruise ships wishing to operate in United States ports. ${ }^{134}$ For the purposes of this paper, the Cruise Vessel Safety Act is significant due to the jurisdiction in which it is said to apply. Like fishing vessels operating in the EEZ, cruise ships operating in and out of United States ports are, by the nature of their voyage and the requirements themselves, effectively required to comply with these unilateral standards throughout the entirety of their voyage, not simply when they are in port. ${ }^{135}$

While it is tempting to view this as an exercise in extra-territorial jurisdiction, in fact the application of the Cruise Vessel Safety Act begins only when the vessel in question enters a United States port, ${ }^{136}$ thus coming under the prescriptive and enforcement jurisdiction of the United States. As Molenaar notes, the extra-territorial effect is therefore incidental, rather than purposeful, with the significant point being that regardless of where noncompliance begins or occurs, it continues within the jurisdiction of the port. ${ }^{137}$ The Act does not affect the flag State jurisdiction of the vessel outside of the port, as the vessel is free, if it so chooses, to not come under the jurisdiction of the port State. ${ }^{138}$ Marten attributes the success of the law to the economic significance of the United States to the cruise industry, ${ }^{139}$ which incentivises operators to comply with the law. In the case of FCVs, this incentive on foreign vessels to enter the jurisdiction of the

\footnotetext{
${ }^{133}$ Molenaar, above n 67, 232

${ }^{134}$ Marten, above n 52, at 78

${ }^{135}$ Marten, above n 52, at 74

${ }^{136}$ Marten, above n 52, at 74

${ }^{137}$ Molenaar, above n 67, 230

${ }^{138}$ Marten, above n 52, at 79

${ }^{139}$ Marten, above n 52, at 71
} 
port State is enhanced through it being a legal requirement, should those vessels which to fish in the EEZ.

No cruise vessel operators opposed the law, ${ }^{140}$ and indeed there are several significant instances of the unilateral prescription of standards where the implementation of such standards has gone unprotested at the international level. ${ }^{141}$ One of the most significant arguments against this method of the prescription and enforcement of vessel standards is through the New Zealand Court of Appeal, in the case of Seller v Maritime Safety Authority. The well-known case relates to an instance in which William Sellers, the master of a pleasure vessel flagged to Malta, was convicted of failing to adhere to New Zealand maritime regulations regarding the carriage of a safety radio and location beacon, a requirement of New Zealand, not international, law. ${ }^{142}$ His subsequent appeal to the conviction was upheld by the Court.

In supporting Sellers' argument that the requirement infringed on his freedom of navigation of the high seas, Justice Keith held that the Director of Maritime Safety could only impose conditions on vessels which were consistent with acceptable international standards and rules, ${ }^{143}$ and that the requirements set by New Zealand regulations impinged upon the exclusive flag State jurisdiction of vessels on the high seas. Justice Keith rejected the Crown's argument that the economic effect on New Zealand which would result from a search and rescue operation in the absence of the equipment gave it jurisdiction to prescribe high seas equipment requirements. ${ }^{144}$ Arguments in support of this judgement have likewise focussed on the importance of the high seas jurisdiction, correctly rejecting any extra-territorial jurisdiction New Zealand would have over the vessel in that maritime area under UNCLOS, but incorrectly suggesting that under UNCLOS no provision for the setting of port exit requirements exists in international law. ${ }^{145}$

In light of the analysis of international law provided above, it is submitted that such an analysis is incorrect, and that more favourable arguments can be found in the opposing

$\overline{{ }^{140} \text { Johanna Jainchill "Cruise lines say ships nearly compliant with new safety rules." Travel Weekly }(9}$ August 2010)

${ }^{141}$ Marten, above n 52, at 232

142 Dermott Devine "Port state jurisdiction: a judicial contribution from New Zealand" (2000) 24 Marine Policy 215 , at 215

${ }^{143}$ Sellers $v$ Maritime [1999] 2 NZLR 44

144 Devine, above $\mathrm{n} 142$, at 216

145 Devine, above n 142, at 217 
view. These arguments bring the focus of the court's decision away from the high seas, suggesting that the decision is the result of a desire of the Court to uphold the limitation of generally agreed standards under UNCLOS, including port State control agreements, contradicts these same standards in ignoring the savings clauses often found in them which recognise the right of the port State to exceed their provisions. ${ }^{146}$ The essence of such an argument is that the requirement to have the equipment is in fact on applicable within the territorial jurisdiction of the port State, not the high seas. As Marten succinctly puts it 'the master in Sellers could have jettisoned his newly-purchased radio as soon as he was outside of New Zealand's waters, but he ought to have been compelled to comply with the authorities' safety standards while within New Zealand's jurisdiction. ${ }^{147}$

Criticisms of the sellers verdict aside, the argument by Maritime New Zealand appears to be that the regulation of such standards by New Zealand would sit outside the existing jurisprudence anyway, in that the required equipment relates directly to the commercial activity governed by the Coastal State, not to navigation and flag State jurisdiction, i.e. the exploitation of living resources within the EEZ. ${ }^{148}$ Such an argument is presumably taken against article 62 of UNCLOS, which provides the right for the coastal State to set conditions on vessels for the utilisation of living resources. However, in the opinion of this author, such an argument would be subject to easy challenge, in that the same Part of UNCLOS also provides for the explicit jurisdiction the flag State over Articles 88-155 in the EEZ, ${ }^{149}$ including the construction, manning, and equipment of ships. ${ }^{150}$ Alternatively, the port State approach alleviates any such challenge to the setting of vessel standards.

It is submitted here then that not only would the framing of vessel standards as a matter of port State jurisdiction provide clear jurisdiction over the standards of foreign fishing vessels operating in New Zealand waters, but that there is no reason such an approach would provide less jurisdiction than it would to New Zealand registered ships. Such an approach could provide a solution to a number of issues identified regarding FCVs, including the lack of provision of safety equipment, the inadequacies of permanent aspects of accommodation and amenities, and the condition and maintenance of the vessel itself, all issues identified during the initial controversy regarding FCVs. This

\footnotetext{
${ }^{146}$ Molenaar, above n 67, 232

${ }^{147}$ Marten, above n 52, at 81

148 Swain et al, above n 4, at 71

${ }^{149}$ UNCLOS Art 58.2

${ }^{150}$ UNCLOS Art 94
} 
could conceivably also include the appropriate certification of seafarers. ${ }^{151}$ Furthermore, this could be achieved without the formal ratification of international conventions such as STCW-F or the Torremolinos Protocol, as recommended by the Ministerial Enquiry as it sought to achieve this regulatory effect. ${ }^{152}$

\section{Employment conditions}

\section{A The Fisheries Act and the Code of Practice}

Issues of employment and labour conditions, particularly concerning remuneration for work, but also relating to hours of work and the settlement of disputes, arguably represent the area of the most complexity in the legal regime for FCV use. Attempts have been made to regulate these aspects of FCVs in the past, most notably in the extension of the protection of wages. Key to this is the provisions of section 103 of the Fisheries Act which deem workers on FCVs working under temporary visas employees for the purposes of the Minimum Wage Act 1983, and the Wages Protection Act 1983; however, in determining the employer, the Act States the following: ${ }^{153}$

the employer of a person referred to in paragraph (a) shall be deemed to be,-

(i) if the operator of the vessel is the employer or contractor of those persons, the operator:

(ii) in any other case, the person from whom the operator has, by virtue of a lease, a sublease, a charter, a subcharter, or otherwise, for the time being obtained possession and control of the vessel

Section 103 further extends jurisdiction to the New Zealand Employment Tribunal and Employment Court to hear disputes related to the clauses above, while also allowing for Labour Inspectors to undertake their duties on FCVs in New Zealand waters, pursuant to the Employment Relations Act 2000. ${ }^{154}$ Nothing in the Fisheries Act affords any broader labour rights to foreign workers on FCVs.

Important here is the wording in section (b) (ii), which requires the employer to be not only the charterer, but also the person in 'possession and control' of the vessel. This wording limits those working on FCVs to being employed by overseas owners or operators of the vessel, as the NZCP of a time charter cannot reasonably be said to be in

\footnotetext{
${ }^{151}$ Marten, above $\mathrm{n}$ 52, at 194

152 Swain et al, above $\mathrm{n} 4$, at 89

${ }^{153}$ Fisheries Act 1996, s 103

154 Fisheries Act 1996, s 103
} 
either possession or control of the vessel. ${ }^{155}$ Effectively, this results in workers on FCVs being employed by foreign employers, under foreign labour laws. ${ }^{156}$ It follows that key statutes of New Zealand employment law are not applicable to FCV workers and employers, such as the Health and Safety in Employment Act 1992. ${ }^{157}$ Additionally, the application of the Accident Compensation Act 2000 has been questioned as to its applicability to FCV workers.

While these provisions are admirable in their intent, they have been subject to significant criticism, and as discussed above have proved largely ineffective in practice, with continued instances of underpayment, unfair deduction of wages or deductions without the agreement of both parties to the employment agreement, excessive hours worked, and unhygienic or unsafe workplaces and procedures. Jennifer Delvin highlights the tensions that occur when trying to prescribe New Zealand employment law to private employment contracts of an international nature. Noting that the conflict of laws principle holds that the objective common law which applies to the contract is the system of law with the closest and most real connection to that contract, the combination of the work taking place within the EEZ and the parties being both foreign nations means that New Zealand law will not apply unless expressly held to. ${ }^{158}$ In referring to the wage protection afforded by section 103 of the Fisheries Act, she further questions whether the applicable Acts could be held as being intended to have extra-territorial effect. ${ }^{159}$

Regardless of the applicability of New Zealand law, Dalvin criticises the employment avenues for dispute settlement as overly difficult and resulting in disincentives for employees to take such disputes. These disincentives begin with the falsification of documents by the masters of the vessels and threats against the work or their families. These are compounded by the lack of English language skills in FCV employees, as well as an unawareness of their rights. ${ }^{160}$ On the occasion that a dispute over wages reached the courts, in the case of Karelrybflot $A O v$ Udovenko, in which the workers of a Russian FCV sued for unpaid wages and damages relating to the extended period of time the plaintiffs were required to remain in New Zealand without employment. ${ }^{161}$ Ultimately, the Court of Appeal awarded unpaid wages equal in amount to New Zealand's minimum

\footnotetext{
155 Dawson and Hunt, above n 6, at 206

156 Swain et al, above $\mathrm{n}$, at 74

157 Swain et al, above n 4, at 75

158 Delvin, above n 22, at 84

${ }^{159}$ Delvin, above n 22, at 85

${ }^{160}$ Delvin, above $\mathrm{n} 22$, at 87

${ }^{161}$ Delvin, above n 22, at 86
} 
wage, based on the provisions of the Fisheries Act, but awarded over a 40 hour week dictated by Russian law, as opposed to actual hours worked. The claim of damages was rejected as the plaintiffs 'elected to remain in New Zealand, where they could enter into employment, instead of accepting reparation.' 162

In seeking to rectify these issues, more substantial rights are provided for workers in the Code of Practice, which in effect attempts to hand the responsibilities of the employers under New Zealand law to the New Zealand Charter Party. Prior to receiving approval in principle for the issuance of temporary visas for the workers, the NZCP under the Code must provide evidence of compliance with suitable standards of accommodation, food, medical supplies and services, and protective clothing. ${ }^{163}$ A representative of the New Zealand party is also required to be available to workers while the vessel is in port. Finally, the New Zealand Charter Party, in complying with the Code of Practice, is required to sign a Deed of Guarantee in which the NZCP acts as the guarantor and becomes liable for unpaid wages equalling the minimum wage plus an additional \$2 per hour, and for the actual hours works or at least a 42 hour week, ${ }^{164}$ a significant increase on the requirements of the Fisheries Act.

However, the nature of the Code of Practice is that it is a piece of immigration policy developed under section 13A of the Immigration Act 1997. The Code seeks to extend New Zealand law outside of New Zealand territory and into the EEZ, despite the administrative jurisdiction of a vessel being held by the flag State, and it does so without empowerment under the Immigration Act to make policy with extra-territorial effect. ${ }^{165}$ This, in Delvin's opinion, leaves the agreement 'very vulnerable to an administrative law challenge,' were it ever tested in a New Zealand court. ${ }^{166}$ Further criticism comes from Dawson and Hunt, who note that the practical difficulties of the dispute settlement procedures in relation to the Deed of Financial Guarantee provided by the Code render it ineffective. ${ }^{167}$ A 90 day limitation period within which to pursue unpaid wages is seen as unpractical for non-English speaking nationals navigating the New Zealand legal system,

\footnotetext{
162 Delvin, above $\mathrm{n} 22$, at 87

${ }^{163}$ Department of Labour, Seafood Industry Council and New Zealand Fishing Industry Guild Inc Code of Practice on Foreign Fishing Crew (19 October 2006), at 9

${ }^{164}$ Department of Labour, Seafood Industry Council and New Zealand Fishing Industry Guild Inc Code of Practice on Foreign Fishing Crew (19 October 2006), at 44

${ }^{165}$ Delvin, above $\mathrm{n} 22$, at 96

${ }^{166}$ Delvin, above n 22, at 96

${ }^{167}$ Dawson and Hunt, above n 6, at 206
} 
while their also exists no guarantee that wages will be paid in the event that the New Zealand party has insufficient funds to fulfil their obligation. ${ }^{168}$

The reflagging of vessels to New Zealand removes these issues by extending the full scope of New Zealand employment law to fishing vessels operating in the EEZ, including the Health and Safety Act (which applies to all New Zealand ships, regardless of their location), ${ }^{169}$ and the Employment Relations Act (through clarifying the 'employer' of the workers as the New Zealand operator of the vessel). The system of law for employment contracts extending into the EEZ also becomes without question that of New Zealand, unless the parties to the contract agree otherwise. However in such a case the minimum rights afforded to workers by New Zealand law (as the objective common law of the contract), would continue to apply. ${ }^{170}$

\section{B Through the use of Port State Jurisdiction}

With regard to the provision of appropriate medical supplies, protective clothing, accommodation, and food, the regulation of this could be provided in the same manner as any other piece of equipment or vessel standard, as discussed in the preceding section. However, with regard to crew wages and employment agreements, it is worth reiterating here the unambiguous jurisdiction of the flag State over a vessel's social and administrative measures, both within the territorial sea (subject to the right of innocent passage), and in all maritime zones beyond that, including the EEZ. Unlike the regulation of vessel standards and equipment, where the same infringement occurs both on the high seas and in the port, instances of unpaid wages and excessive work hours are clearly related to the activity as it occurs at sea.

The issue of port State jurisdiction regarding employment matters is further complicated by its relationship with international civil law, as evidenced both in the section above and in the general discussion on port State jurisdiction provided earlier in the paper. This would suggest no obvious benefit could be derived through port State jurisdiction relating to the issues highlighted above, as it is unlikely that the fact that a vessel is in port would shift the weight of the objective common law in New Zealand's favour. However, two possible approaches are worth comment here; the first is the use of port State jurisdiction to ensure that vessel operators hold insurance over particular aspects of their vessel; the

\footnotetext{
168 Dawson and Hunt, above n 6, at 207

${ }^{169}$ Health and Safety in Employment Act 1992 s 3B

${ }^{170}$ Delvin, above n 22, at 84
} 
second is the existing State practice regarding the application of the full scope of domestic employment laws through the use of port State jurisdiction.

One potential application in the assurance of crew wages could be found in a variation of the port entry requirement for compulsory ship insurance found in the European Union's 2009 Insurance Directive. The Directive States that 'Each member State require shipowners of ships flying a flag other than their own to have insurance in place when ships enter a port under the Member State's jurisdiction. ${ }^{171}$ While this is generally applied with respect to environmental damages that may be incurred by the ship while in port, it is not limited to this. For example, State practice in the United Kingdom sees it extend 'any liability for the cost of providing relief to, and of repatriating, seamen left behind or shipwrecked." ${ }^{172}$ While relating to cases where a crew member has been stranded by a disaster, the key point here is the ability for States to require financial guarantees in order to comply with the regulations of the port State.

In relation to FCVs, this consideration is not unprecedented. The Foreign Fishing Crew Wages and Repatriation Bond Bill 2000, though eventually amended to the point of near irrelevance due to fishing industry pressures, aimed to protect the financial position of foreign fishing crews if their New Zealand operator went into receivership. ${ }^{173}$ Similarly, the possibility of requiring a fund for FCV workers' wages is suggested by Dawson and Hunt in their review of the Code of Practice. ${ }^{174}$ The Bill, like the Code of Practice, held the New Zealand party responsible for the provision of the funds should the employer of the crew fail to pay. However, it is conceivable that the requirement for the master of a ship to provide evidence of both the availability and payment of wages could be undertaken as a requirement for port entry and exit.

While port State jurisdiction provides one avenue for achieving this regulatory outcome, the question of whether it provides a unique way of achieving this is questionable. Given the requirement for vessels to register as fishing vessels under the Fisheries Act and the ability for conditions to be set against that registration, the same effect could arguable be achieved within the existing law. However, such an approach could have further applications beyond crew wages. For example, the requirement to hold medical and

\footnotetext{
${ }^{171}$ Marten, above n 52, at 123

172 The Merchant Shipping (Compulsory Insurance: Ships Receiving Trans-shipped Fish) Regulations 1998, s 5(d)

173 Paul Myburgh “Shipping Law” (2003) 1 NZ L. Rev. 287, at 290

174 Dawson and Hunt, above n 6, at 207
} 
income protection insurance for employees injured in their course of work would both encourage safer working practices on-board the vessels, and also alleviate the ambiguities regarding the applicability of the Accident Compensation Act 2000 to FCV employees. Notwithstanding the ability for States to impose requirements for entry to ports as they wish, there is a natural desire to see such a requirement as an infringement of the administrative aspects of a ship operating under the jurisdiction of the flag State. The framing of such a provision as a port State requirement rather one attempting to infringe on the flag of the vessel could find precedence in the Seaman Wages Act of the United States. This act saw the disembarkation of an unpaid seaman into a United States' port as a direct burden on the port, and thus an offence by the ship and its master. ${ }^{175}$ Likewise, the departure of an injured or unpaid worker into New Zealand from a vessel could be regarded as a direct burden on the State. Such a measure, taken through the port State, could afford FCV workers with employment welfare provisions which would normally be imposed at the discretion of the flag State.

Whether port State jurisdiction could achieve the full application of New Zealand employment law, as will be achieved through reflagging, would appear likely to be answered with a 'no'. Instances of State practice in the application of domestic employment legislation to vessels wishing to enter their ports are rare. The Clay Bill of the United States of America is one such example, which sought to extend American wages protection and employment rights (such as collective bargaining), to ships entering US ports. This bill subsequently did not pass into law, and was held as being contrary to the 'internal economy' (internal effects) principle, thereby rejecting the application of any domestic employment legislation onto a foreign vessel (whether in port or not), ${ }^{176}$ before the issues relating to private international law raised by Delvin have even been acknowledged. The combination of ambiguities relating to civil law, and limited State practice in the application of employment law would suggest that such measures would be highly ineffective next to the reflagging of vessels to that State.

\section{Employee abuse}

\section{A The Fisheries Act, pre-2014.}

Interestingly, despite the media attention given to instances of serious abuse onboard FCVs, little attention has been paid to the legal concerns of this issue, either scholarly or

\footnotetext{
$\overline{175}$ Jason M. Schupp “The Clay Bill: Testing the Limits of Port State Sovereignty” (1994)18 Md. J. Int'1 L. 199 , at 221

176 Schupp, above n 175,at 226
} 
through the Ministerial Enquiry into FCV use. Instead, attention has focused more directly on the issues identified above. Submissions to the Ministerial Enquiry stressed that this was as issue confined to Korean flagged FCVs, while disputes on vessels with alternate flags were solely in the realm of underpayment of wages. ${ }^{177}$ While claims have been made to the New Zealand Police on the issue of human rights abuses, no prosecutions or investigations have been undertaken. ${ }^{178}$ The primary issue for New Zealand authorities in hearing such claims of abuse is cited as the 'limited criminal jurisdiction over foreign flagged vessels.' ${ }^{179}$ This limited jurisdiction is certainly the case within the EEZ, as detailed above, a fact reinforced through the absence of matters of abuse from Section 103 of the Fisheries Act, ${ }^{180}$ and the vagueness of the Code of Practice, which simply requires the NZCP to undertake its own investigations into complaints relating to 'fishers' welfare.' 181

Following the reflagging of fishing vessels to New Zealand in 2016, any fishing vessels operating within New Zealand waters will unquestionably be subject to New Zealand's criminal law, which applies to any offence committed on a commonwealth ship. ${ }^{182}$ For FCVs, the Ministerial Enquiry for its part recognized the seriousness of the claims of abuse in recommending that 'consideration be given to how the provisions of the Crimes Act 1961 might be applied to the activities of foreign flagged FCVs in New Zealand's EEZ.' 183 The key aspect of that Statement, activities ...in New Zealand's EEZ, is the main concern of this section. Generally, the Crimes Act only applies within the 12NM territorial sea (therefore including New Zealand ports), save for certain instances of extraterritorial jurisdiction. ${ }^{184}$ In exercising criminal jurisdiction over FCVs, the applicability of extra-territorial principles to those acts committed would need validation, or alternatively, the offence would have to be construed in such a way as it could be considered to have been committed within the area of New Zealand's territorial jurisdiction.

\footnotetext{
177 Swain et al, above $\mathrm{n}$ 4, at 76

178 Swain et al, above $n$ 4, at 77

179 Swain et al, above n 4, at 77

180 Delvin, above n 22, at 88

181 Department of Labour, Seafood Industry Council and New Zealand Fishing Industry Guild Inc Code of Practice on Foreign Fishing Crew (19 October 2006), at 7

182 Crime Acts 1961, s 8

183 Swain et al, above $\mathrm{n}$ 4, at 74

${ }^{184}$ Crimes Act 1961, s 8
} 


\section{B Through the use of Port State Jurisdiction}

While the potential for extra-territorial jurisdiction could be used to overcome the exclusivity of flag State jurisdiction over crimes committed on vessels in the EEZ, allowing for in port enforcement, extra-territorial principles can be easily dismissed when related to FCVs. For example, despite the seriousness of the crimes reported, which arguably are at least as serious as high seas violence caused by piracy, the universality principle could not be applied. As Lowe and Stevens put it, the applicability of the universality principle to piracy at sea relates more to the lack of jurisdiction by any State which would otherwise be afforded over the offence, rather than the seriousness of the crime itself. ${ }^{185}$ As such, crimes as serious as murder and abuse are not subject to the universality principle. Equally, as no New Zealand nationals were subject to the offenses detailed above, the national principle can easily be dismissed as irrelevant here. Given that New Zealand permits these vessels to operate in its waters, and therefore can equally deny them that right, it would be equally hard to argue that the apparent threat FCV abuses had to New Zealand's international reputation or economic interests could constitute jurisdiction over its 'vital interests' under the protective principle. Finally, while the effects principle has been applied to crimes which have had an economic impact on a State, ${ }^{186}$ as it could be argued the publicity surrounding FCVs did to New Zealand, this appears to be reserved for instances where the intention of the crime has a direct effects the state, rather than this being an incidental effect of the crime.

Given their limited scope, the use of extra-territorial jurisdiction in general should be seen as offering little value to the regulation of crime between crew on-board foreign vessels. ${ }^{187}$ Questions may arise as to whether a coastal State can take enforcement measures against a person or vessel which has committed a crime in the EEZ while transiting to a port. However, UNCLOS holds that enforcement by the coastal State against criminal acts occurring in the EEZ is limited to the violation of environmental laws, or laws governing the utilisation of living resources. ${ }^{188}$ Were instance of abuse to occur in a port or in the territorial sea while transiting to port, New Zealand could enforce these. However, instances of abuse on board FCVs in the EEZ are well beyond the ability of the port State to enforce, regardless of whether that vessel is utilising the resources of the coastal State's EEZ, and therefore port State jurisdiction offers little that could change this.

\footnotetext{
185 Lowe and Staker, above n 51, at 327

${ }^{186}$ Lowe and Staker, above n 51, at 322

${ }^{187}$ Marten, above n 52, at 10

${ }^{188}$ Haijiang, above $\mathrm{n}$, at 252
} 
While it is unlikely that port State jurisdiction could be extended in any way to offences which occur within the EEZ, could it be possible that it could be used to allow for the monitoring of crime on-board FCVs? While such instances of abuse on FCVs could not be followed up with prosecution by New Zealand (at least without approval from the flag State of the vessel), evidence that such abuse was occurring could result in de-registration of the offending vessel under section 103 of the Fisheries Act. This would accordingly result in the removal of the vessel from the New Zealand fishing industry, a measure analogous to the outcomes of the Fisheries Amendment Act, which has not resolved the problems of abuse on foreign fishing vessels but rather removed New Zealand's role in facilitating their ongoing operation.

State practice relating to the monitoring of crime on foreign vessels as a port State requirement brings the discussion back to the United States' Cruise Vessels Safety and Security Act. In addition to the standards discussed above, the Act also prescribes requirements for the maintenance of on-board video surveillance and staff procedures regarding access to passenger cabins aboard foreign flagged cruise ships should those ships wish to enter United States ports. Furthermore, it requires the collection and publication of data relating to on-board crime for applicable ships. ${ }^{189}$ Noting the port State enforcement focus of the Act as discussed above, these provisions nonetheless apply to a voyage that departs from, or will arrive at, a United States' port, ${ }^{190}$ suggesting that as with vessel standards, the implementation of the requirements relates to the entire voyage. As such, the ability to legally prescribe such requirements would be sufficient to monitor any instances of abuse occurring in the EEZ on-board FCVs.

The ability of a State to require that such systems as video surveillance be installed on a vessel is consistent with the port State enforcement of equipment requirements discussed above. Interestingly, the provision of video surveillance on board EEZ fishing vessels has been incorporated into the Fisheries Amendment Act as part of the provision for observers on board these vessels; however the use of this equipment is limited to the monitoring of fishing and transportation. ${ }^{191}$ Allowance for reporting on matters of employment and safety is provided to observers themselves, a measure which is by its nature reliant on the resources the Department of Labour has to provide sufficient coverage. While placing the enactment of the requirement to maintain records of crimes

\footnotetext{
${ }^{189}$ Marten, above n 52, at 69

${ }^{190}$ Marten, above n 52, at 74

${ }^{191}$ Fisheries Amendment Act 2014 s 13
} 
and video surveillance on foreign vessels meets the issues of the coastal State attempting to prescribe vessel operations on foreign ships, the framing of this requirement as a port entry requirement removes the infringement of jurisdiction. The requirement of compliance with prescribed ship borne operations on the high seas as a port entry requirement has no explicit restrictions in international law. ${ }^{192}$

The utilisation of a port entry requirement for the reporting and monitoring of abuse could therefore be extended to FCVs in New Zealand's EEZ, with vessels required to comply should they wish to fulfil their legal obligations in respect to the landing of fish. Therefore, while the use of port State jurisdiction could not be used to prosecute instances of abuse on board FCVs as envisaged by the Ministerial Enquiry, it could be used in such a way that brings greater transparency to such abuse, allowing for the deregistration of offending vessels. The limitation of this is of course that surveillance could not practically be provided for the whole ship, and any requirement to keep logs of alleged crime would undoubtedly be subject to the falsification of documents, as was prevalent in the issues detailed in this paper. As with employment on FCV then, the use of port State jurisdiction could go some way to addressing this issue, but is ultimately far from being as effective as the impending reflagging of fishing vessels.

\section{Conclusion}

The growing importance of the port State in the regulation of international shipping is recognized in the growth of port State control agreements, as well as the increasing unilateral prescription of port requirements by States such as the United States of America, and those of European Union. While this regulatory regime can afford States significant control over foreign vessels operating in their waters and ports, the extent to which it could provide suitable regulation of Foreign Charter Vessels operating in New Zealand's waters varies depending on the issue being addressed. In response to the question originally posed by this paper, without question, the reflagging of foreign charter vessels resolves any and all ambiguities regarding jurisdiction over fishing vessels operating within New Zealand's EEZ more than any other regulatory regime could. However, the ambiguities and criticisms regarding FCVs which were raised during the Ministerial Enquiry could have, in some instances at least, been appropriately mitigated through the application of laws based on port State jurisdiction.

${ }_{192}$ Marten, above n 52, 101 
Principally among those issues is the question of vessel standards. There should be no question as to New Zealand's ability to regulate and enforce the level of construction, design and equipment standards of those vessels which voluntarily enter its ports. Indeed, all the Fisheries Amendment Act may have achieved in this regard is the alleviation of the need to amend the various Maritime Rules not already applicable to FCVs. Equally, there is the potential for a greater guarantee of workers' wages being paid should a dispute arise, a point that is not insignificant given the prevalence of the issue of unpaid wages. However, those offences which occur within the EEZ, and which are the most serious of those identified, are explicitly beyond the jurisdiction of New Zealand. For this reason alone the passing of the Fisheries Amendment Act should be seen as a much more appropriate solution to the issues identified than to that which could be provided through port State jurisdiction.

Given the change in law, the discussion provided here may appear as a largely academic in a New Zealand context. However, given the need for small developing nations to rely on foreign vessels to fully exploit their total allowable catches, ${ }^{193}$ the discussion is not necessarily irrelevant in the broader context of international maritime law. If this is the case, perhaps this paper is best regarded as further evidence of the need for greater international involvement in the regulation of fishing vessels. If, as Hare put it, port State control is the most effective means of regulation for international shipping, ${ }^{194}$ then based the discussion above on unilateral State action, and coupled with the lack of relevant international conventions, the safety of crew on international fishing vessels is a long way from being effectively regulated.

\footnotetext{
${ }^{193}$ Swain et al, above $\mathrm{n} 4$, at 24
}

${ }^{194}$ Hare, above n 65, at 594 


\section{BIBLIOGRAPHY}

\section{A Journal Articles}

Aldo Chricop "Living with Ships in Distress - A New IMO Decision Making Framework for the Requesting and Granting of Refuge" (2004) 3 WMU 31.

Anne Bardin "Coastal State's jurisdiction over foreign vessels” (2002) 14 Pace Int'l L. Rev. 27.

Blaise Kuemlangan and Michael Press, "Preventing, Deterring and Eliminating IUU Fishing - Port State Measures" (2010) 40 Envt'l Pol'y \& L.262.

Camille Goodman "The Regime for Flag State Responsibility in International Fisheries Law - Effective Fact, Creative Fiction, or Further Work Required?' (2009) 23 Austl. \& N.Z. L.J. 157.

Christina Stringer, Glenn Simmons and Daren Coulston "Not in New Zealand's waters, surely? Linking labour issues to GPNs" (2013) 14 Journal of Economic Geography 739.

Christopher F. Murray “Any Port in a Storm? The Right of Entry for Reasons of Force Majeure or Distress in the Wake of the Erika and Castor" (2002) 63 Ohio St. L. J. 1465.

Dermott Devine "Port State jurisdiction: a judicial contribution from New Zealand" (2000) 24 Marine Policy 215

Erik Jaap Molenaar "Port State Jurisdiction: Towards Comprehensive, Mandatory and Global Coverage" (2007) 38 ODILA 225.

Jason M. Schupp "The Clay Bill: Testing the Limits of Port State Sovereignty” (1994)18 Md. J. Int'l L. 199 
John Hare "Port State Control: Strong Medicine to Cure a Sick Industry" (1996-1997) 26 Ga. J. Int'l \& Comp. L. 571

Jennifer Devlin "Modern Day Slavery: Employment Conditions for Foreign Fishing Crews in New Zealand Waters" (2009) 23 Austl. \& N.Z. Mar. L.J. 82

Louise de La Fayette "Access to ports in international law" (1996) 11 Int'1 J Marine \& Coastal L 1.

Paul Myburgh "Shipping Law” (2003) 1 NZ L. Rev. 287

Peter Dawson and Renee Hunt 'The Legal Regime Governing the Operaiton of Foreign Charter Fishing Vessels in New Zealand' (2011) 25 Austl. \& N.Z. L.J. 195.

Ted. L. McDorman "Port State Enforcement: A Comment on Article 218 of the 1982 Law of the Sea Convention" (1997) 28 J. Mar. L. \& Com. 305

\section{B Books and Chapters in Edited Books}

Aldo Chircop "The Customary Law of Refuge for Ships in Distress" in Aldo Chircop and Olof Linden (ed) Places of Refuge for Ships: Emerging Environmental Concerns of a Maritime Custom (Martinus Nijhoff Pulishers, Leiden, 2006) 163.

Bevan Marten Port State Jurisdiction and the Regulation of International Merchant Shipping (Stringer International Publishing, Heidelberg, 2014).

Donald R Rothwell and Tim Stevens The International Law of the Sea (Hart Publishing, Oregon, 2010).

Haijiang Yang Jurisdiction of the Coastal State over Foreign Merchant Ships in Internal Waters and the Territorial Sea (Stringer International Publishing, Heidelberg, 2006).

Vaughan Lowe and Christopher Staker "Jurisdiction" in Malcolm D. Evans (ed) International Law (3 ${ }^{\text {rd }}$ ed, Oxford University Press, Oxford, 2010) 313. 
Yoshifumi Tanaka The International Law of the Sea (Cambridge University Press, Cambridge, 2012)

\section{Research Papers}

Hannah Brown "A fine kettle of fish: Employment conditions on foreign charter vessels in New Zealand's Exclusive Economic Zone" (LLB (Hons) dissertation, Victoria University of Wellington, 2012)

\section{Ministerial Reports}

Paul Swain, Sarah McGrath and Neil Walter Report of the Ministerial Inquiry into the use and operation of Foreign Charter Vessels (Ministry of Agriculture and Forestry, February 2012).

\section{E Cases}

Sellers v Maritime [1999] 2 NZLR 44

\section{F Legislation}

$1 \quad$ New Zealand

Crimes Act 1961

Employment Relations Act 2000

Fisheries Act 1996

Fisheries (Foreign Charter Vessels and Other Matters) Amendment Act 2014

Health and Safety in Employment Act 1992

Maritime Rule Part 21 Safe Ship Management Systems (21 August 1997) 
Maritime Rule Part 40D Design, Construction and Equipment - Fishing Ships (1 February 2000)

Maritime Transport Act 1994

Ship Registration Act 1992

\section{United Kingdom}

The Merchant Shipping (Compulsory Insurance: Ships Receiving Trans-shipped Fish) Regulations 1998

\section{G Looseleaf materials}

Department of Labour, Seafood Industry Council and New Zealand Fishing Industry Guild Inc Code of Practice on Foreign Fishing Crew (19 October 2006).

Maritime New Zealand "Safe Ship Management: Your Guide to Entry" (online looseleaf ed, Maritime New Zealand, 2009).

\section{H Parliamentary Materials}

Auroha Fisheries Limited "Submission to the Primary Production Committee on the Fisheries (Foreign Charter Vessels and Other Matters) Amendment Bill 2012”

Maruha (N.Z.) Corporation Limited "Submission to the Primary Production Committee on the Fisheries (Foreign Charter Vessels and Other Matters) Amendment Bill $2012 "$

Primary Production Committee Fisheries (Foreign Charter Vessels and Other Matters) Amendment Bill (25 July 2013)

Sealord Group Limited "Submission to the Primary Production Committee on the Fisheries (Foreign Charter Vessels and Other Matters) Amendment Bill 2012” 
Sanford Limited "Submission to the Primary Production Committee on the Fisheries (Foreign Charter Vessels and Other Matters) Amendment Bill 2012"

\section{Hansard}

(15 April 2014) 698 NZPD 17281

(30 July 2014) 700 NZPD 19655

\section{J International Agreements}

Working in Fishing Convention C188 (opened for signature 14 June 2007, not yet in force)

International Convention for the Safety of Life at Sea 1184 UNTS 3 (opened for signature 1 November 1974, entered into force 25 May 1980)

International Convention on Standards of Training, Certification and Watchkeeping for Fishing Vessel Personnel, (opened for signature 7 July 1995, entered into force 29 September 2012)

Maritime Labour Covention UTNS (opened for signature 23 February 2006, entered into force 20 August 2012).

Memorandum of Understanding on Port State Control in the Asia-Pacific Region (Tokyo MoU) (adopted 1 December 1993)

United Nations Convention on the Law of the Sea 1833 UNTS 3 (opened for signature 10 December 1982, entered into force 16 November 1994). [LOSC]

\section{K Newspaper Articles}

Benjamin E. Skinner "Fishing as Slaves on the High Seas" Bloomberg Businessweek (United States of America, 20 February 2012). 
Johanna Jainchill "Cruise lines say ships nearly compliant with new safety rules." Travel Weekly (9 August 2010)

Yvonne Tahana "Maori quota holders sidestep foreign-worker law: Where they come from” New Zealand Herald (Auckland, New Zealand, 27 July 2013)

\section{Online Material}

David Carter and Kate Wilkinson "Foreign charter vessels to be reflagged" (22 May 2012) Beehive.govt.nz http://www.beehive.govt.nz/release/foreign-chartervessels-be-reflagged

"Status of Conventions" (31 August 2014), International Maritime Organisation http://www.imo.org/About/Conventions/StatusOfConventions/Pages/Default.aspx

"Ratifications of C188 - Work in Fishing Convention, 2007 (No. 188)" International Labour Organisation http://www.ilo.org/dyn/normlex/en/f?p=1000:11300:0::NO:11300:P11300_INST RUMENT_ID:312333

\section{Speeches}

Dawson, Peter "Foreign Charter Vessels: A Confused Legal Regime" (Presentation to MLAANZ - NZ Branch Conference, Hilton, Taupo, 27 April 2012). 